\title{
Chlamydia trachomatis. Co-factor or factor in cancer of the cervix?
}

\author{
José Núñe: Troconis \\ Departamento de Obstetricia y Ginecología, Facultad de Medicina. Universidad del Zu- \\ lia. Maracaibo, Venezuela.
}

Key words: Chlamydia trachomatis; cancer of the cervix; inflammation mechanisms; carcinogenesis; sexual transmitted infection.

\begin{abstract}
The objective of this article was to review and to analyze the possible role that Chlamydia trachomatis has as a co-factor in the origin and development of cervical cancer. For that purpose, the Latin-American and international bibliography was reviewed using the Pub-Med, Google Scholar, Springer, the Cochrane Library, Embase, Scielo, Imbiomed-L, Redalye and Latindex databases. The searches included the key words: Chlamydia trachomatis, epidemiology of Chlamydia trachomatis, epidemiology of eervical cancer, Chlamydia trachomatis and infection, Chlamydia trachomatis and inflammation mechanisms, eervical cancer and co-factors, sexually transmitted infections and cervical cancer, cancer and inflammation mechanisms, carcinogenesis, inflammation mechanisms. Publications from 1970 to June 2020 were reviewed and analyzed. This review article analyzes the possible mechanisms that Chlamydia trachomatis could play in the carcinogenesis of the cervical cancer as a co-factor with the human papilloma virus or as an independent factor.
\end{abstract}

Corresponding Author: José Núñez Troconis. Departamento de Obstetricia y Ginecología, Facultad de Medicina. Universidad del Zulia. Maracaibo, Venezuela. E-mail: jtnunezt@gmail.com 


\section{Chlamydia trachomatis: ¿Co-factor o factor en el cáncer del cuello uterino?}

Invest Clin 2021; 62 (3): 247-275

Palabras clave: Chlamydia trachomatis; cáncer del cuello uterino; mecanismo de la inflamación; carcinogénesis; infecciones de transmisión sexual.

Resumen. El objetivo de este artículo fue revisar y analizar el posible papel que la Chlamydia trachomatis tiene como co-factor en el origen y desarrollo del cáncer del cuello uterino. Para dicho propósito, se revisó la bibliografía latinoamericana e internacional en las bases de datos de Pub-Med, Gooǵle Scholar, Springer, la biblioteca Cochrane, Embase, Scielo, Imbiomed-L, Redalyc and Latindex. La búsqueda incluyó las palabras claves: Chlamydia trachomatis, epidemiología de la Chlamydia trachomatis, epidemiología del cáncer del cuello uterino, cáncer del cuello uterino, Chlamydia trachomatis e infección, Chlamydia trachomatis y mecanismo inflamatorios, cáncer del cuello uterino y co-factores, enfermedades de transmisión sexual y cáncer del cuello uterino, cáncer y mecanismos de la inflamación, carcinogénesis, mecanismos de la inflamación. Se revisaron y analizaron publicaciones desde 1970 hasta junio 2020. Este artículo de revisión analiza los posibles mecanismos que la Chlamydia trachomatis pudiera jugar en la carcinogénesis del cáncer del cuello uterino tanto como cofactor con el virus del papiloma humano o como factor independiente.

Received: 01-02-2021 Accepted: 10-04-2021

\section{INTRODUCTION}

Chlamydia trachomatis (Ct) infections are the most commonly reported sexually transmitted bacterial infections, and the most common bacterium responsible for sexually transmitted infections, globally (1). Most (70\%-80\%) of these infections are asymptomatic, often remain undetected and, if not treated, can lead to severe complications, mainly in young women. Advances in diagnostic techniques and methods of specimen collection have made easier the detection, treatment and prevention of these infections of global public health significance (2).

Globally, more than 1 million curable sexually transmitted infections (STIs) occur each day. According to World Health Organi- zation (WHO). The global estimate for 2016, was roughly 376 million new infections (excluded the viral STI), more than 1 million per day, of the four curable STIs: Chlamydia, gonorrhoea, syphilis and trichomoniasis. Trichomonas vaginalis (Tv): 156 millions infections, Ct: 127 millions infections, gonorrhea: 87 millions infections and, syphilis: 6 millions infections (3). According to WHO, the estimation of global prevalence of $\mathrm{Ct}$ in $15-49$ years old women was $3.8 \%$ and the prevalence was found higher in upper and middle income countries. For the American continent, the prevalence was estimated in $7 \%$ (3.8\%-6.6\%). The global incidence rate for Ct in 2016 was estimated to be 34 cases per 1000 women. The American continent had the highest incidence rate for Ct; like- 
wise, the upper and middle income countries, had the higher incidence (4). In 2015, Redmond et al. (5) reported a prevalence of $\mathrm{Ct}$ in women of $3.6 \%$ (range: $3.0 \%-5.3 \%$ ) in countries member of European Union. In our country, Venezuela, different authors have reported an incidence among 12.8\% to $25 \%$ (4-6). One of the major problem is that approximately $2 / 3$ of the world's population has limited access to $\mathrm{Ct}$ screening and treatment programs. The predominantly asymptomatic nature of $\mathrm{Ct}$ infection also results in many undiagnosed individuals who go untreated, and hence, continue to spread infection. These untreated infections could also have other devastating consequences, as Ct infection can also increase susceptibility to, and transmission of others STIs such as gonorrhea, Tv, Human Immunodeficiency Virus (HIV), Human Papillomavirus (HPV), Hepatitis virus C (HVC), etc. (9).

Among the risk factors to get a $\mathrm{Ct}$ infection, it could be mentioned: early age in the initiation of sexual activity, especially in women under 20 years old, unmarried status, nulliparity, black race, poor socio-economic conditions, multiple sexual partners, promiscuous sexual partner, new sexual partner, smoking habit, lack of use of barrier contraceptive devices and concurrent gonococeal infection (10-14). In addition, cervical chlamydial infections are found to be associated with the use of oral contraceptives (14).

The objective of the present study was to review and to analyze the relationship of $\mathrm{Ct}$ infection with the eervical eancer (CG).

\section{MATERIAL Y METHODS}

Literature searches were performed electronically in PubMed, Medline, ISI, DOAJ, Springer, Embase, Web of Knowledge, DOAJ, Google Scholar and the Cochrane Library for original articles written in the English language and in Scielo, Lantidex, Imbiomed-L, Redalye and Google Scholar for original articles written in Spanish. Selection criteria included randomized clinical trials, observational trials, open-label nonrandomized trials, and case reports related to $\mathrm{Ct}$ and CC. The Cochrane Library was searched for reviews. Publications from 1970 to June 2020 were reviewed.

The searches included the key words: Chlamydia trachomatis, epidemiology of Chlamydia trachomatis, epidemiology of cervical cancer, Chlamydia trachomatis and infection, Chlamydia trachomatis and inflammation mechanisms, cervical cancer and co-factors, sexual transmitted infections and cervical cancer, cancer and inflammation mechanisms, earcinogenesis, inflammation mechanisms.

\section{Chlamydia trachomatis}

Microorganism

Chlamydiae are a Gram-negative, spherical or ovoid obligate intracellular bacteria and have a unique, generally biphasic, developmental cycle. Infectious, non-replicative elementary bodies (EBs) infect genital columnar epithelial cells and reside within a membrane-bound vacuole termed an inclusion but not able to divide. Here, EBs differentiate into non-infectious vegetative reticulate bodies (RBs), which are metabolically active and able to replicate, to grow into the cell and to differentiate back into EBs, and exit cells via lysis or extrusion mechanisms; EBs released into the mucosal lumen can then infect nearby epithelial cells or be transmitted to sexual partners via genital secretions $(2,9,15)$. Within 8-12 divisions (16), differentiation to EBs is initiated and the cycle is complete when the cell releases the contents of the inclusion to attach to adjacent cells and reinitiate the cycle. Ct has DNA and RNA, multiply by binary fission rather than self-assembly, contain their own ribosome, have a peptidoglycan free cell wall $(1,17)$. Chlamydiae can be classified into 19 serovars or serotypes (genovars) based on antigenic variation in the major outer membrane protein (MOMP) epitopes encoded by ompA $(1,17)$. Serovars or serotypes A, B, $\mathrm{Ba}$ and $\mathrm{C}$ are associated with trachoma, se- 
rovars or serotypes D-K are most commonly with urogenital infection and serovars or serotypes L1-L3 represent strains causing invasive lymphoma granuloma venereum (LGV) (see Table I).

\section{Mode of transmission}

The mode of transmission is by sexual contact or intercourse. Chlamydial infection can occur at any anatomical site of sexual contact including endocervix, urethra, rectum, and oropharynx (1).

\section{Clinical manifestation}

\section{Infections in women}

Chlamydial infection in women is commonly asymptomatic (18). Women with cervicitis/endocervicitis can be asymptomatic or may complain of mucopurulent vaginal discharge or throughout the external orifice of the cervix and/or postcoital bleeding. Edema, congestion and bleeding of the cervix have been observed. Urethral infection can be associated with cervicitis. A culture-negative leucocyturia finding is suggestive of $\mathrm{Ct}$ infection. Ascending infections can result from cervicitis. Endometritis is frequently associated with this and may produce irregular uterine bleeding; the endometritis can be acute or chronic. Other pathologies, because of the ascending infections, are salpingitis and pelvic inflammatory disease (PID). They are often subclinical and $\mathrm{Ct}$ is the cause of least $60 \%$ of cases of acute PID $(2,19)$. Salpingitis may lead to tubal scarring and severe reproductive complications. Two-thirds of all cases of tubal factor infertility and $1 / 3$ of all cases of ectopic pregnancy could be due to chlamydial infection $(2,20,21)$. Chronic pelvic pain linked to the presence of peritoneal adhesions may occur in more than 15\% of women with previous episodes of PID $(2,19)$. Salpingitis and peritoneal adhesions are associate to infertility and ectopic pregnancy (21). Ct is also considered a leading cause of PID and female infertility worldwide. Fitz-Hugh-Curtis syndrome, a perihepatitis observed after or in conjunction with salpingitis, is more commonly associated with $\mathrm{Ct}$ than with gonococeal infections (2). There is little evidence, and this is conflicting, to implicate $\mathrm{Ct}$ in chorioamnionitis and adverse pregnancy out-come $(2,19)$. Postpartum endometritis occurs in $30 \%$ of women with antenatal chlamydial infection. In both men and women, Ct may be involved in conjunctivitis by auto-inoculation from the genital tract (2) (see Table I).

TABLE I

Chlamydia trachomatis

CLINICAL MANIFESTATIONS

\begin{tabular}{lll}
\multicolumn{1}{c}{ Serovar } & \multicolumn{1}{c}{ Clinical Manifestation } & \multicolumn{1}{c}{ Complications } \\
\hline A-C & Keratoconjunctivitis & Scarring trachoma, blindness \\
D-K & Male: urethritis, proctitis & Male: epididymitis \\
& Female: cervicitis, urethritis, proctitis, & Female: acute and chronic pelvic inflammatory \\
& endometritis, salpingitis. perihepatitis & disease: pelvic pain, ectopic pregnancy, Fiztz- \\
& Male and female: conjuntivitis & Hugh-Curtos syndrome, infertility. \\
& & Male and female: Reiter's syndrome, reactive \\
& & arthritis.
\end{tabular}

L1-L3 Lymphogranuloma venereum: Fibrosis, rectal stricture inguinal syndrome, proctitis 


\section{Infections in men}

$C t$ is the major cause of non-gonococeal urethritis and post-gonococeal urethritis. Urethritis can be complicated by acute epididymitis in young men. After 7-21 days of incubation, the symptoms include dysuria, and a moderate clear or whitish urethral discharge $(2,20)$. Acute proctitis can be associated with oculo-genital serovars or serotypes, but is usually milder than that associated with LGV serovars. There is no evidence of the role of $C t$ in prostatitis (22), and chlamydial infection does not significantly contribute to male infertility (23). Reiter's syndrome (urethritis, conjunctivitis, arthritis and mucocutaneous lesions) or reactive arthritis have also been associated with genital $C t$ infections, with a high male/female ratio (22). (see Table I).

\section{Pathogenesis}

Immunopathogenesis

$C t$ is a strong immunogenic, which stimulates both humoral and cell mediated immune responses. In addition to the immunogenic antigens, the outcome of chlamydial infection depends on the interaction and balance of cytokines secreted by the activated lymphocytes. Interferon gamma (IFN- $\gamma$ ) has been described as the single most important factor in host defense against $C t$, while disease susceptibility has been linked with enhanced expression of interleukin-10 (IL10). Immune system changes or disturbances induced by $C t$ may favor its own survival in the infected host, and induce persistent infections (11). Ct infection may be primary or a chronic/recurrent/re-infection.

Primary infection: A serial infection of the mucosal cells is seen during the primary infection. The damaging and infected epithelial cells secrete numerous pro-inflammatory chemokines and cytokines, including IL-1, IL-6, IL-8, granulocyte-macrophage colony stimulating factor (GM-CSF), growth regulated oncogene, and tumor necrosis factor alpha (TNF- $\alpha)(11 / 24,25)$. The released cytokines cause vasodilatation, increased endothelial permeability, activation and influx of neutrophils, monocytes and T-lymphocytes, and elevated expression of adhesion molecules. In addition, it stimulates other cells to secrete cytokines. Neutrophils appear to play a role in reducing the initial amplification of $C t$ and possibly in limiting the spread within the female genital tract. IL-1 is secreted initially by the undamaged cells and stimulates the secretion of other cytokines from other non-infected cells, like TNF- $\alpha$ (26). During the same period, $C t$ passes via lymphatic vessels to local lymph nodes. The decaying epithelial cells release a few EBs, which are phagocytosed by neutrophils through phagolysosomes.

$\mathrm{T}$ lymphocytes, mainly $\mathrm{T}$ helper cells (Th1), play an important role during early phase of infection, which, due to $C t$ antigeninduced activation, secrete IFN- $\gamma$, necessary for infection regression. It increases the potential of various phagocytes to destroy $C t$ and stimulates the secretion of other cytokines, including IL-1. IL-1, in turn, by stimulating the secretion of IL- 2 by Th1 cells, it causes increased replication of cytotoxic lymphocytes and natural killer cells. The role of secretory IgA has also been established in the neutralization of primary infection $(11,27)$. It has been observed that a single acute episode of chlamydial infection cannot lead to serious sequelae associated with this infection; persistent infection may be responsible for the serious consequences (11).

Chronic infection/recurrent/reinfection: Chronic infection, associated with persistence of $C t$ in the host cells, recurrent infection or reinfection are more dangerous. A delayed hypersensitivity reaction or rarely, type 3 hypersensitivity reactions (Arthus reaction) is observed in the long term or recurrent stimulatory action of chlamydial antigens. Antibodies are not involved in the delayed type of reaction developing within 24-48 hrs due to antigen interaction with specifically sensitized Th1 lymphocytes. Processes, which occur during these reactions, lead to tissue damage, fibrosis and cicatriza- 
tion within the affected organs. Irreversible consequences, like PID leading to mechanical infertility, ectopic pregnancy, chronic pelvic pains and chronic urethritis, may occur. After a single episode of salpingitis about one in 10 patients become infertile because of tubal occlusion. After 2-3 episodes, infertility ensues in about $35-70 \%$ cases. In several studies, repeated chlamydial infection was associated with PID and other reproductive sequelae, although it was difficult to determine whether the risk per infection increased with recurrent episodes (28). Lack of treatment or improper therapeutic management may result in chronic infection. A significant role of dietary factors like insufficient supply of tryptophan, L-isoleucine and cysteine in diet, as well as certain cytokines like INF- $\gamma$, TNF- $\alpha$, have been observed and reported (29). Formation of atypical chlamydial forms in vitro has been demonstrated in INF- $\gamma$ treated cells. The atypical forms (29) are large, non-infectious, have reduced metabolic activity, and do not replicate, yet remain alive. Such atypical forms display decreased levels of MOMP and lipopolysaccharide (LPS) antigens but continue with high production of chlamydial heat shock protein 60 (hsp60), which is capable of inducing chronic inflammation and scarring. Chronic and occult infections pose several diagnostic and therapeutic problems. Due to the variable antigenic structure of atypical forms, the routine diagnostic methods do not always identify them. Moreover, these forms have reduced MOMPs, which lead to decreased transport of antibiotic across the cell. Therefore, in case of chronic infections, therapy frequently results in failure.

Reinfection is due to the repeated infection, while recurrence is caused by the presence of a $C t$ reservoir in the lymph node and spleen (29). Macrophages have been found to play an important role in the recurrence of infection as $C t$ circulates within the macrophages, finding a temporary shelter in the lymph nodes, spleen and serous cavities. It has been observed that recurrences were more frequent in young patients with prolongation of the active period in comparison with patients in older age group (30). The less common spread of infection in the older age group has been attributed to low exposure to $C t$ and by physiological changes which reduce sensitivity to the acquisition (29).

\section{Inflammation and cancer}

Inflammation is mediated by immune cells as an immediate defense in response to infection or injury by noxious stimuli. Innate immune cells such as neutrophils, mast cells, and macrophages possess receptors that signal the activation and production of an array of biologically active proteins and defense molecules in response to foreign substances as well as to damaged or altered self-molecules $(31,32)$. The infiltration of immune cells into sites of solid tumors, observed first by Rudolf Virchow in 1863 (31) has for many years been pursued as a failed effort of the immune system to resist tumor development. Though this is true and the basis of tumor escape from immune surveillance, Virchow's idea that the immune cells associated with tumors reflected a role for these cells in the origination of cancer was the first to suggest that the immune cells 'themselves' were active participants in tumor development.

\section{Inflammation and tumor development}

It is now well recognized that the presence of inflammatory cells commonly precedes tumor development (33). Demonstration that inflammation plays a causal role in tobacco-related carcinogenesis, viral carcinogenesis and asbestos-associated carcinogenesis highlights the significance of inflammation in tumorigenesis. Substantial evidence from both experimental models and human studies have demonstrated that inflammation fosters the development of tumors by acting on or with the cancer hallmarks identified by Hanahan et al. (34). This includes effects on evasion of apoptosis, 
uncontrolled growth and dissemination, as well as altering/deregulating tumor immune surveillance. In fact, Colotta et al. (33) suggested that inflammation be considered a separate cancer hallmark, an idea supported in the update to the cancer hallmarks, where because of the broad acting role of inflammatory cells in tumor development, Hanahan et al. (34) conceptualized the role of inflammation as one of 'enabling' or cause of tumorigenesis.

Acute inflammation possesses two balanced and biologically opposing effector arms represented in a 'yin' (pro-apoptotic or tumoricidal) and 'yang' (wound healing or pro-tumorigenic) relationship model, where immune cells participate with the non-immune cells in the local environment (e.g. epithelial, vasculature and neuronal) (35). Unresolved and persistent inflammation has been described as the loss of or deregulation in the balance between the 'yin' and 'yang' responses. The role of persistent inflammation as a contributing factor in tumorigenesis is well accepted and, in many cancers, thought to be a necessary component. Examples include a causal relationship between inflammation and infectious agent-associated cancers [e.g. hepatitis $B$ and $\mathrm{C}$ virus (liver), human papilloma virus (e.g. cervix, anal) and the bacterium Helicobacter pylori (stomach)]. The relationship between eancer and inflammation is also supported by the elevated risk of cancer in chronic inflammatory conditions, such as colitis-associated colorectal cancer. Importantly, the cause-effect relationship between inflammation and cancer is a challenging concept as it implies that inflammation precedes the processes. However, current evidence widely suggests that in the case of cancer, which is a multi-step and complex process, inflammation is an integral component of the overall pathogenesis of disease at the microenvironment level that not only contributes in a causal way but also supports a permissive state for tumors to grow (34). As such, it is important to recognize that tumor-associated inflammation (TAI) in solid tumors is itself a complex pathologic process, with contributions from classic immune cells as well as poorly characterized, cancer-associated fibroblasts and the epithelial tumor cell compartment (31).

\section{Cellular mechanisms of inflammation and tumorigenesis}

Over the past two decades, our understanding of inflammation in tumorigenesis has led to the identification of a number of molecules that are strongly linked to the development of human cancers $(33,36,37)$. Like tumorigenesis, tumor-promoting inflammation and TAI are the phenotypic product of a complex set of cellular and molecular interactions that result in an imbalance in local microenvironment that is most analogous to an unresolved 'wound-healing' response (37). The cellular and molecular composition of TAI has been the subject of a number of extensive recent reviews (31$33,35,37,38)$.

A number of the cellular and molecular mechanisms involved in inflammation induced tumor initiation, promotion, and progression are now well described (see Table II). These inflammation-induced changes occur at the cellular and tissue level. Among the best characterized are the pro-inflammatory and mutagenic reactive oxygen (ROS) and reactive nitrogen species (RNS), cytokines, chemokines and lipid-derived products of the inducible COX-2 in arachidonic acid metabolism including the highly potent prostaglandin (PG)-E 2 . At physiological levels, ROS and RNS are important cell signaling molecules (39), however, at high levels or with aberrant production, ROS and RNS are capable to cause considerable cellular damage resulting in cell injury, DNA damage and an inflammatory response $(40,41)$. During tumorigenesis, ROS and RNS have been characterized for their ability to induce a plethora of effects on cells and on the local environment that include DNA damage, adduct of cellular protein and lipids, and in 
TABLE II

MOLEGULES, GELLS AND TISSUES ALTERATIONS WITH CHRONIC INFLAMMATION AND TUMOR PROMOTING CONSENQUENCE

Genomic instability, chromosome remodeling, epigenetic changes and altered gene and miRNA expression

Altered post-translational modification, activity and localization of cell proteins

Altered cell metabolism

Induction of cell growth and anti-apoptotic signals $\rightarrow$ uncontrolled cell growth and retention of cells with damaged genomes

Vasodilation, leakage of the vasculature and infiltration of leukocytes $\rightarrow$ disrupted tissue integrity and altered microenvironment and immunosuppression and recruitment of myeloid suppressor cells

Altered cell polarity $\rightarrow$ disturbance in stroma/epithelial tissue matrix and loss of differentiation signals

Tissue necrosis $\rightarrow$ neovascularization and hypoxia

Induction of matrix metalloproteinases $\rightarrow$ invasiveness and spread

the absence of apoptosis at high levels, promotion of abnormal cell proliferation and transformation (39). High levels of ROS and RNS are produced by the innate immune system in response to tissue injury or damage. ROS and RNS are produced in response to cell-damage by inflammatory cells. The unresolved damage leads to a potential vicious cycle producing chronic and high levels of ROS and RNS. These high levels and chronic exposure of cells to ROS and RNS from macrophages and mast cells are linked to a range of tissue pathologies, including neurodegenerative and autoimmune diseases, along with the propagation of mast cells that are thought to promote myeloid-suppressor cell expansion that inhibit tumor immunosurveillance as well as to maintain the tumor promoting microenvironment $(39,42,43)$. This deregulation of ROS and/or RNS production have been, and continue to be investigated as biological indicators as potential exogenous and endogenous cause of cancer, independent of the DNA damage (31).

\section{Cyclooxygenase, prostaglandins and their receptors}

The eyclooxygenase (COX) enzymes were among the first identified molecular targets of interest in TAI. There are three COX 
isoforms: COX-1 or prostaglandin G/H synthase 1 (PTGS1), which is constitutively expressed; COX-2 (PTGS2), the inducible form of the COX enzymes; and COX-3, an alternative variant of COX-1. COX enzymes catalyze the formation of lipid mediators, including prostanoids, prostacyclins and thromboxanes. COX-2 is over-expressed in acute and chronic inflammation as well as in tumors. Extensive research efforts over the past three decades have established a strong link between COX-2 expression, inflammation, and eancer. COX-2 suppression prevents neoplasia in numerous rodent models of cancer as well as in human clinical trials (44); several epidemiological studies have reported lower cancer rates in regular users of aspirin and other non-steroidal anti-inflammatory agents that are now explained by the inhibitory activity of these drugs on the pro-inflammatory/ pro-tumorigenic effects of PGE-2 $(44,45)$. COX-2 ean be induced by a number of factors including cytokines, chemokines, ROS and environmental chemicals. Induction of COX- 2 activates mPGES- 1 , the inducible enzyme that catalyzes the COX-2-derived lipid intermediate PGH-2 to PGE-2, the biological mediator of the tumorigenic effects of COX2. PGE-2 is the most abundant PG in solid tumors and has been shown to influence tumor cell growth, migration and invasiveness. The tumorigenic actions of PGE-2 are numerous and include the induction of angiogenesis, transactivation of the epidermal growth factor receptor, inhibition of apoptosis and immunosuppression (46). The physiological and pathological effects of PGE-2 are mediated through interactions with specific $\mathrm{PG}$ receptor subtypes present on multiple cell types, including most immune cells and epithelial cells. PGE-2 shows the highest affinity for the EP receptor subtypes 1-4 (PTGER1-4 or EP14). All four of the EP receptors are present on the majority of cells involved in immune responses $(47,48)$. Under normal conditions, PGE-2 attenuates the activity of macrophages and dendritic cells by inhibiting the production of tumor necrosis factor (TNF)- $\alpha$ and interleukin (IL)-10. The EP2 and EP4 receptors mediate these activities as well as regulate the proliferation and differentiation of $\mathrm{T}$ and B cells. And while it is clear that the biological activities of PGE-2 is determined by the nature and distribution of the EP receptors, very little is known about the EP receptor subtype/PGE-2 interactions, interaction with environmental chemicals, interaction with bacterial and virus infections. It is important to recognize that COX-2 expression is regulated by a number of transcription factors that its deregulation could lead to the sustained induction of COX-2 as a co-factor in TAI. These include the hypoxia inducible factors (HIF- $1 \alpha$ and HIF- $2 \alpha$ ), NF- $\mathrm{NB}$, and signal transducer and activator of transcription (STAT) $(49,50)$.

STAT family proteins regulate cytokinedependent inflammation and immunity. STAT protein family members, including STAT 1-6, are over-expressed in a number of human cancers. The role the STATs in TAI has recently been well established in prostate cancer where chronic inflammation is believed to play a major role in tumor development (51). STAT3 has been linked to the induction and maintenance of an inflammatory microenvironment in the prostate and to the malignant transformation and progression due to the maintenance of a pro-inflammatory state. The pro-inflammatory cytokine IL-6 is a potent inducer STAT3 where binding to the IL6R induces activation of the Janus tyrosine family kinase (JAK)-signal transducer leading to a phosphorylation dependent activation STAT3. STATs, like other transcription factors, have a dual role in inflammation and is considered to be both a friend and an enemy of tumorigenesis (52). They can be induced by inflammation and they can induce inflammation by activating $\mathrm{NF} \kappa \mathrm{B}$ and IL-6 pathways. The activation of $\mathrm{IKK} \beta / \mathrm{NF} \kappa \mathrm{B}$ is potent stimuli for IL- 6 and thus activation of the STAT3 protein. Inflammation is an established risk factor for hepatocellular cancer (HCG) from viral infection and other environmental or drug insults. 
STAT3 is over-expressed in the majority of HCG in human with high levels correlated with IL-6 levels in the local tumor (53), findings that support a role of IL-6 and STAT3 as a TAI phenomenon in HCC in humans. Given the role of STATs in inflammation, and evidence as an important signaling molecule in TAI, the STAT transcription factors represent an important and unexplored family of molecules as putative mediators of TAI in the presence of environmental chemicals, biological and other toxicants (31).

\section{Cytokines as immune effector molecules}

Cytokines are a large group of small proteins $(5-20 \mathrm{kD})$ that act as a paracrine and autocrine messengers with a wide spectrum of biological functions across numerous tissue and cell types. Collectively, the cytokines include chemokines, interferons, interleukins, lymphokines and tumor necrosis factors (TNF). Cytokines are produced by cells of the immune system: $\mathrm{B}$ and $\mathrm{T}$ lymphocytes, macrophages, mast cells, stromal cells: endothelial cells and fibroblasts, as well as tumor cells. Cytokines exhibit paracrine and autocrine effects on a wide range of tissues and cells. The cytokine most consistently associated with tumor cell killing is TNF $\alpha$. After TNF $\alpha$ interacts with its receptor, a subsequent chain of cellular events leads to the activation of the transcription factor, nuclear factor (NF)- $\kappa \mathrm{B}$ and subsequent production of IL-1 $\beta$, IL-6, IL-8 and IL-17. In the simplest mechanistic model, these pro-inflammatory molecules are coupled to each other via TNF- $\alpha$ binding to its receptor (TNFR), which activates the NF-kB pathway in the acute phase response. This results in the up-regulation of a group of pro-inflammatory cytokines as a programmed response to wounding or infection. It is this response that is triggered in the initial response to injury or infection (54) but when it is unresolved or chronic, is widely believed to promote tumorigenesis and contribute or enable tumor progression.
Under homeostatic conditions, two membrane receptors, TNFR1 and TNFR2, mediate the actions of the TNF family of molecules (55). While initially described as an anti-tumor molecule, the role of TNF- $\alpha$ as protumorigenic is now well characterized. Tumor and inflammatory cells within the tumor microenvironment produce $\mathrm{TNF} \alpha$, supporting tumorigenesis and metastasis by promoting: genomic instability through the production of ROS and RNS, cell survival by deregulating apoptotic pathways, promoting invasion through induction of matrix metalloproteinases (MMPs), and angiogenesis via the induction of pro-angiogenic factors. Part of this response may be due to the presence of TNFR1 on tumor, stromal and immune cells, thereby allowing TNF- $\alpha$ to exert its activity both directly on the tumor and indirectly within the tumor microenvironment to sustain local inflammation and recruitment of cells with inhibitory effects on tumor immunity. The effects of TNF $\alpha$ as a pro-tumor molecule have been clearly demonstrated in TNFR1-deficient mice, which are resistant to tumorigenesis. The best-characterized mechanism of the tumor-promoting effects of TNF- $\alpha$ are those related to the tumor cell itself and molecular alterations, such as mutation, deletion and amplification, in key regulatory genes that lead to the constitutive activation and deregulated activation of NF- $\kappa \mathrm{B}$. More recently, the role of non-genetic factors in the overproduction of TNF- $\alpha$ has been is recognized (31). In the presence of active NF- $\kappa \mathrm{B}$ signaling, TNF- $\alpha$ and NF- $\mathrm{KB}$ interact to induce cytokines: IL-1, IL-6, COX- 2, adhesion proteins and MMPs. The high levels of theses inflammatory cytokines trigger uncontrolled NF- $\mathrm{KB}$ expression and activation, preventing the resolution of the response $(33,36)$. The adaptation to the local microenvironment stressors is thought to place a selective pressure on tumor cells that promotes angiogenesis and the escape of tumor cells from the toxic environment; two critical cancer hallmarks of metastasis (31). 
Along with TNF- $\alpha$, IL- 6 is among the most commonly over-expressed cytokine in human tumors (56). IL-6 can act as a double-edged sword. Induced in response to injury or infection, IL-6 can induce COX-2 expression and PGE2 synthesis as well as function in the resolution phase of an acute response by inhibiting TNF $\alpha$ and IL-1 and by inducing other anti-inflammatory cytokines such as IL-10. Thus, IL-6 exhibits both anti- and pro-inflammatory actions at the site of a wound or lesion (31). In the tumor, IL-6 has been shown to negatively regulate apoptotic processes, making cells more resistant to cell death. Two types of IL-6 receptors, membrane-bound and soluble (57). The membrane bound IL-6 receptor is predominantly expressed in hepatocytes, lymphocytes, neutrophils, monocyte/macrophages and epithelial cells. After binding to IL-6, the receptor associates with the signaltransducing protein gp130 to initiate its signaling cascade. The interaction with gp130 promotes a negative feedback loop responsible for the anti-inflammatory effect of IL-6. The soluble IL6 receptor (IL-6R) is present in body fluids and is linked to the inflammatory action of IL- 6 in cells not expressing IL6R. In this case, the IL-6/IL-6R complex can bind to gp130, which is expressed in all cell types, thus explaining the broad spectrum and systemic action associated with IL-6 in inflammation (31).

The diverse functions of IL-6 are linked to interactions across distinet signaling pathways, including the MAP/STAT pathway and the AKT/PI3K signaling eascade, which negatively regulates apoptosis and promotes cellular proliferation. Recently, IL-6 has been shown to play a key role in maintaining the balance between the regulatory subclass of T cells (Treg) and Th17, an effector T cells that produces IL-17, IL-6, TNF- $\alpha$ and other pro-inflammatory chemokines (58). This function, which is a very important in immunity and immune pathology, is linked to the inflammation process which, when chronicity is maintained, promotes the onset of malignancies in different organs and that acts to suppress tumor immune surveillance and tumor killing through the recruitment of immunosuppressive myeloid suppressor cells (59).

Along with IL-6, a number of other cytokines that participate in inflammation and present in TAI, have been implicated in tumor metastasis. In the case of IL- 8 and IL-17 (60), these two pro-inflammatory cytokines have the ability to induce neo-vascularization and to enhance the activity of the matrix-degrading enzymes MMP-2 and MMP-9 (61). IL-8, which is also known as CXCL8, is a potential therapeutic target for a number of inflammatory diseases given its critical role in innate immune responses and as a chemoattractant for neutrophils (31). The activity of IL- 8 is mediated by binding of monomeric or dimeric forms of CXCL8 to one of its two receptors CXCR1 and CXCR2. Expressed normally on the surface of leukocytes, these receptors have also been shown to be up-regulated on both tumor and tumor-associated stromal cells in a variety of cancers including lung, prostate and, colorectal. Via CXCR1/2, IL-8 activates several important signaling pathways that are overactive in tumors (MAPK, PI3K, PKC, FAK and Sre) and which function in tumor cell proliferation and migration. IL-8 pathway signaling is induced by a number of factors including inflammatory eytokines:TNF- $\alpha$, IL-1, ROS, and steroid hormones. There is evidence that IL-8 and CXCR1/2 signaling are major drivers in chronic inflammation including TAI.

Like IL-8, the IL-17 molecule is a recently recognized potent pro-inflammatory cytokine that is produced by the Th17 subpopulation of $\mathrm{T}$ lymphocytes and is thought to be involved in tumorigenesis (60). After binding to its receptor, IL-17RA, IL-17 activates the MAPKs ERK1/2 and p38, PI3K/Akt and NF- $\kappa \mathrm{B}$ pathways, leading to the production and secretion of IL-1 $\beta$, IL- 6, TNF $\alpha$ and IL-8, as well as CXCL1 and CXCL6, which attract neutrophils. The importance of IL- 
17 in tumor development is supported by observations that inhibition of IL-17 in animal models of colorectal carcinogenesis prevents tumor formation, an effect that both prevent the pro-inflammatory response and the effect of the pro-inflammatory response on tumor specific immunity (31).

\section{Lipoxygenases and lipoxins}

The lipoxygenases/lipoxins products of polyunsaturated fatty acid metabolism represent a more recently recognized of bioactive metabolites in inflammation. Th 5-lipoxygenase (5-LOX) has been implicated in inflammation-related neoplasia. 5-LOX is a non-heme iron dioxygenase that synthesizes leukotrienes, lipoxins, resolvins, and protectins from different substrates belonging to the polyunsaturated fatty acids (62). The 5-LOX is located in the cytoplasm or nucleus and is activated in the nucleus where it translocates to interact with 5-lipoxygenase activating protein to mediate the transfer of arachidonic acid from the membrane to 5-LOX. Besides its role in inflammation, the overexpression of 5-LOX occurs in a number of tumor tissues and cell lines (63). The final products of 5-LOX, such as 5-hydroxyeicosatetraenoic acid and leukotrienes A4 and B4 (LTA4 and LTB4) contribute to cell survival and growth. The inhibition of 5-LOX enzymatic activity or the silencing of 5-LOX and leukotriene receptor expression attenuates the metastatic phenotype in colon cancer cells (64). As with the COXs, there are anti-proliferative effects with 5-LOX inhibitors such as AA861, zileuton, nordihydroguaiaretic acid and 5-LOX activating protein inhibitors such as MK 886, MK 591. These molecules induce apoptosis in breast (65), leukemia (66) and pancreatic (67) cell lines. As such, much like the interest in COX2 and PGE2, the LOX pathway is emerging as an important mediator of tumorigenesis with direct effects on tumor-associated and tumor-promoting inflammation (31).

\section{Chlamydia trachomatis and cervical cancer}

Epidemiology of cervical cancer

In 2018, according to the International Agency for Research on Cancer/Globocan (IARC) (68), the cervical cancer (CG) was the ninth more frequent cancer worldwide including both sexes, with 569.847 new cases, representing an incidence of $3.2 \%$ among all the cancers, and caused 311.365 deaths (incidence: $3.3 \%$ ), being the ninth type of cancer that caused more deaths worldwide (68). CC represents the second most common female organ cancer worldwide, after breast cancer (68). The Pan-American Heath Organization/World Health Organization (PAHO/ WHO) (69) reported 72,000 new cases of CC and almost 34,500 deaths in the American continent during 2018. The mortality rate was three times higher in Latin-America and the Caribbean area than in North-America (69).

Chlamydia trachomatis and inflammation

$C t$ has been found repeatedly to associate with cervical intraepithelial neoplasia (CIN) and CG (70,71), although the association has commonly been thought to be the result of confounding by HPV (72). A possible explanation for the association of $\mathrm{Ct}$ and CC might be that the $C t$-induced inflammation results in an impaired ability to clear HPV infections (72). The vaginal microenvironment may be considered a co-factor in the pathogenesis of CIN/CC (73-75). The influence of different infectious agents and their association with HPV in cervical carcinogenesis has not yet been fully known (76). It is believed that persistent HPV infection in the cervical epithelium is facilitated by inflammatory processes caused by other STI pathogens. Among the main etiological agents responsible for STDs that may be potentially involved in cervical carcinogenesis are $C t$, Herpes Simplex Virus (HSV) 1 and 2, Neisseria gonorrhoeae (Ng), Mycoplasma genitalium (Mg), Trichomonas vaginalis (Tv), and Treponema pallidum (Tp), which eause 
inflammatory processes and microabrasion or microtrauma on the cervical epithelium, deteriorating the infection scenario and promoting the persistence of HPV $(77,78)$.

Protective immunity to $C t$ infection is limited and repeated episodes of infection are common. It is believed that the inflammation associated with genital tract disease is immunologically mediated. Persistent antigen synthesis and an ineffective immune response largely contribute to chronic inflammation, tissue damage and immunopathology $(79,80)$. Previous exposure to $C t$ offers limited protection against reinfection because the protection is mostly serovar or serotype specific and is due to antibody specific for MOMP, which defines the serovar o serotype (81). Cell-mediated immunity has to offer most of the protection against Ct. Genital infection by $C t$ and the resulting cytokine environment together with the route of antigen presentation determine the outcome of infection and disease $(82,83)$. The expression of cytokines within the tissue regulates the recruitment of specific subsets of lymphocytes to distinct parts of genital tract $(84,85)$ so the outcome of genital chlamydial infection depends on the $C t$ serovar or serotype and the host immunological responses to infection and the balance between the pathogen specific Th1 and Th2 cell responses (86). While the critical role of eytokines and lymphocyte subsets recruitment in infection has been reported in different animal models, there is little information available in humans about the nature of immunological events occurring in the female genital tract following infection with $C t(83,85)$. Local regulation of $\mathrm{CD} 4+$ and CD8 + lymphocytes and the role of Th1/Th2 responses in the genital tract during $C t$ infection are considered to be crucial for controlling the duration of infection (79).

Different cytokines have been detected in cervix and fallopian tube in response to $C t$ infection; the major cytokines found up-regulated were: IFN- $\gamma$, IL-10, IL-12 and TNF- $\alpha$. High levels of IFN- $\gamma$ have been reported in the endocervical secretions of $C t$ positive women (87). Further, the antichlamydial activity of CD4 + and CD8 + T-cells is primarily associated with the production of high levels of IFN- $\gamma$ (88-90). Beatty at al. (91) have reported that INF- $\gamma$ promotes the destruction of $C t$ and also triggers macrophage release of inflammatory mediators that cause fibroblast proliferation, thereby enhancing the synthesis of collagen. In addition, IFN- $\gamma$ delays the developmental cycle of $C t$ so that chlamydial RBs persist longer, which might result in persistent unapparent infection and also, play a role in immunopathogenesis by promoting inflammatory damage (92).

Reddy et al. (79) reported that Ct infection also up-regulated the cervical production of TNF- $\alpha$ which plays an important role in the initiation of inflammatory response. The same authors (79) found a marginal increase in the cervix in their study. It is reported that IL-1 is important both for the recovery process and for causing inflammatory response (93).

Increased levels of IL-12 have been observed in cervical secretions of $C t$ positive women (79). It was suggested that IL-12 is important for the initial clearance of bacteria $(83,84,94,95)$. Further, IL-12 is required for promoting IFN- $\gamma$ production by NK cells (96). Phagocytosis of $C t$ induces dendritic cells (DCs) to produce IL-12, which in turn promotes Th- 1 response and induces the presentation of chlamydial antigen to CD4+Tcells (96), also there is an increase in IL-6 production in the cervix infected by $C t$ (79).

Levels of Th- 2 cytokine, IL-10 has been found to be high in cervical secretions, thereby showing that the immune response in $C t$ infection of a mixed type, with both IFN- $\gamma$ and IL-10 being up regulated. In addition, IL-10 is not always an inflammatory/ inhibitory cytokine; instead high levels of IL-10 probably prevent the pathological effects of the inflammatory cytokines like, IL1 , IFN- $\gamma$, TNF- $\alpha$, etc. (97).

$C t$ infects squamous epithelial cells in the cervix, often inducing an acute inflam- 
matory reaction, followed by lymphocytic infiltration and the development of lymphoid follicles. CD4 + and CD8 $+\mathrm{T}$ cell responses are interdependent and are required for optimal immunity to $C t$ infection. However, more studies are needed to define the individual contribution of CD4+ and CD8+ T-cells in determining the T-helper cell response (Th1, Th2 or Th0) during chlamydial pathogenesis in the human female genitals (79).

Chlamydia trachomatis de-regulated and damage host DNA

About $15 \%$ of human cancers can be attributed to virus infection, and viruses are second after tobaceo as risk factors for cancer. In the future, a major proportion of these infections may be preventable by immunization, significantly reducing the worldwide cancer burden. The importance of the experimental study of tumor viruses in animals and human is illustrated by the fact that oncogenes and tumor suppressor genes were first identified through their interaction with tumor virus proteins $(98,99$, 100-102). There are two major mechanisms by which oncogenic viruses induce tumors (98,103-106): 1.- direct oncogenesis, the virus infects a progenitor of the clonal tumor cell population, and usually persists in the tumor cells and, 2.- indirect oncogenesis occurs when the virus does not necessarily infect the tumor progenitor cell, but exerts an indirect effect on cell and tissue turnover or in the immune system, predisposing to tumor development. However, assessing an infectious etiology can be difficult (99) because of 1.- subclinical infections are common and this may lead to misclassification bias; 2.- complex interactions can result because many sexually transmitted infections do occur simultaneously; 3 .- the presence of a latency period between exposure and outcome, which vary considerably; 4.- clinical follow-up studies always remain inconclusive (98,103,104,106-109). It was well known and established that the human papillomavirus (HPV) is the principal etiological agent in cervical neoplasia $(103,110-118)$, some other sexually transmitted organisms may either contribute to or protect against cervical carcinogenesis $(70,72,119,120)$.

It is well known the role that HPV especially high risk-HPV (hr-HPV) in the carcinogenesis of CIN/CG. High oncogenic risk HPV genotypes may infect the epithelium persistently, inducing lesion progression and contributing to carcinogenesis. Research has shown that the hr-HPV genotypes detected in carcinoma cases are HPV16, 18, 31, 33, $35,39,45,51,52,56,58,59,68,73$, and 82 , also, it has been detected 3 HPV genotypes that should be considered probably carcinogenic: 26, 53 and $66(118,121)$.

The molecular mechanisms underlying cervical carcinogenesis induced by $C t$ are not fully understood. Genetic damage and neoplastic changes induced in vitro, release of nitric oxide and the inhibition of host cell apoptosis by blockade of mitochondrial cytochrome $\mathrm{C}$ release and caspase activation might account, at least, in part for such mechanisms $(122,123)$. Chromatin alterations, such as histone modifications, may induce somatically heritable changes of gene activity and thus have oncogenic potential (124). Histone post-translational modifications (PTMs) are typically induced by signal transduction pathways activated in response to cellular stimuli. One prominent pathway implicated in histone PTMs is the mitogen-activated protein kinase (MAPK) cascade, which leads to histone H3 serine 10 (H3S10) phosphorylation in a promoterspecific manner, targeting only a subset of genes $(125,126)$. More recently, the chlamydial nuclear effector protein was shown to have histone methyltransferase activity that targets histones H2B, H3, and H4 (127). These data establish that bacterial pathogens induce multiple types of histone PTMs, although the mechanisms and extent of this phenomenon requires elucidation. (127).

Recently, the role of chromatin and histone modifications in promoting DNA damage responses (DDRs) and genome stability 
have gained prominence (128). Upon detection of DNA double-strand breaks (DSBs), cells activate DDR pathways that detect DNA lesions and signal their presence by mediating responses such as cell-cycle arrest, DNA repair, and, under some circumstances, apoptosis. Phosphorylation of H2AX Ser139 $(\mathrm{gH} 2 \mathrm{AX})$ is a prominent chromatin modification in response to DSBs that acts as a signal for recruitment of repair proteins including pATM and 53BP1 to DNA break sites. Deficiencies in DNA damage signaling and repair pathways lead to genetic instability, which in turn might enhance oncogenesis (129).

Chumduri et al. (126) showed that Ct infection of endocervical epithelial cells alters global histone PTMs of host cells. The infected cells showed a hypo-acetylation and hipermethylation of lysine residues on core histones, suggesting that an overall decrease chromatin accessibility and a higher order chromatin structure. Host chromatin perturbations occurred in the context of infection-induced ROS-mediated DNA damage and inhibited DDR. Moreover, infected cells failed to activate cell-cycle checkpoints and continued to proliferate. Thus, these data provide evidence of a cellular mechanism that supports the epidemiological observations associating $C t$ infection with cancers of the female reproductive system.

Histone modifications are increasingly implicated in DDRs and regulation of genome stability, in addition to their accepted roles in transcriptional regulation (128). Currently, there are a limited number of examples that describe the ability of bacterial pathogens to perturb the host epigenome (130). The prototypical carcinogenic bacterium Helicobacter pylori has been shown to alter histone H3 phosphorylation in a typeIV-secretion-system-dependent mechanism (131). More recently, the chlamydial effector protein Nue was shown to have histone methyltransferase activity, which could directly modify mammalian histones (127). Chumduri et al. (126) have shown that Ct infection can lead to extensive alterations of global host histone PTMs. Specifically, $C t$ infection consistently increased levels of phosphorylated $\mathrm{H} 2 \mathrm{AX}$. $\mathrm{gH} 2 \mathrm{AX}$ is a prominent chromatin modification that is up-regulated in response to DSB induction and is important as a signal for the recruitment of repair proteins to DSBs. Another histone modification that is a constituent of the DNA damage histone code is phosphorylation of $\mathrm{H} 2 \mathrm{~B}$ at Ser14 (132), which was also found to be modulated in $C t$-infected cells. Phosphorylation of $\mathrm{H} 4$ at Ser1 (pH4Ser1) has been implicated in the restoration of chromatin structure by preventing re-acetylation and, thereby, shutting down DNA damage signaling after DNA repair (133). Ct infection induced elevated levels of the phosphorylated form of H4Ser1 during acute infection, which might reflect its role in DNA repair activities. Chumduri et al. (126) have observed decreased levels of H3K9Ac and H3K56Ac in infected cells, which have previously been shown to be reduced in response to DNA damage in human cells (134).

Chumduri et al. (126) have provided a comprehensive analysis of global changes to host chromatin induced upon infection with a bacterial pathogen. They (126) have shown that chlamydial infection alters histone PTMs, leading to four distinct patterns of histone marks, which vary between acute and persistent infections. Among others, gH2AX and H3K9me3, hallmarks of DSBs and senescence associate to heterochromatin foci (SAHF), respectively, showed sustained up-regulation during $C t$ infection. Reactive oxygen species induced by $C t$ were found to contribute to persistent DSBs. SAHF formation was selectively induced in an ERK- dependent manner in response to $C t$-induced DSBs, in contrast to DNA damage induced by etoposide. They (126) demonstrated that $C t$ infection suppressed DNA damage repair activities despite the presence of extensive DSBs in host cells. Infected cells containing DSBs continued to proliferate, facilitated by SAHF formation. The same authors (126) have reported that $C t$ infection causes DSB 
generation, which could predispose host cells to genomic instability and transformation via the unusual combination of impaired repair and pro-survival signaling.

According to Chamduri et al. (126) Ct modulates host cell function in ways that convey benefits to the pathogen but have severe consequences for the fate of host cells. These may be relevant during chronic infection. Ct induces the formation of DSBs, which leads to the induction of gH2AX. However, the induction of $\mathrm{gH} 2 \mathrm{AX}$ is not followed by a DDR that would either stimulate the induction of appropriate repair processes or lead to cellular senescence or apoptosis. Instead, infection promotes cellular viability by limiting the extent of DNA damage signaling. Together, the orchestrated deregulation of host cell signaling and perturbations to host cell chromatin lead to the enforced survival of damaged host cells, which is likely to predispose them to transformation.

\section{Chlamydia trachomatis and human papillomavirus}

The pathogenesis of $\mathrm{Ct}$ in Cervical Intraepithelial Neoplasia (CIN)/CG remains unknown; however, different authors (135137) suggest that $C t$ may be involved in cervical carcinogenesis. The cervical metaplasia induced by $\mathrm{Ct}$ can provide target cell for acquisition of $H P V$, especially $h r-H P V$ $(135,138)$. On the other hand, by causing local immune-perturbation because it may interfere with the immune surveillance of $H P V$ infections, especially $h r-H P V$ types, in patients with persistent or chronic infection of $C t(119,139)$. These two alternatives are supported by studies that show that $C t$ infection is a risk factor for the new and persistence of HPV DNA $(72,140)$. However, evidence of $C t$ infection increasing the risk of the development of CIN/CG, among those with or without $h r-H P V$ infection at the baseline, is still missing $(119,122)$.

As it was mentioned before, it is well known that $C t$ causes cervicitis and endocervicitis, which becomes a chronic infection at the endocervical cells of the transformation zone. Such inflammation may predispose women to other STDs, including HPV, HIV, $H S V 1$ and 2, Ng, Mg, To and, Tp infection by damaging epithelial integrity $(120,141)$. Different studies have suggested that a $C t$ infection is associated with a persistence of $h r$ $H P V$ infection $(72,140)$ and persistent $H P V$ infections are necessary for progression to high-grade CIN and CC $(142,143)$. So it is believed that chronic cervical inflammation by $C t$ could increase the risk of transformation of cervical cells that are persistently infected with oncogenic types of HPV (120).

Several factors affect cervical carcinogenesis, from behavioral variables to the presence of infectious agents linked with STIs. This is true especially for high earcinogenesis risk genotypes of the HPV $(123,144)$. There is a huge amount of reports that evidence the incidence of HPV is higher in women with secondary genital infections. The vaginal microenvironment may be considered a co-factor in the pathogenesis of CIN/CG $(145,146)$. The influence of different infectious agents and their association with HPV in cervical carcinogenesis has not yet been fully explained. It is believed that inflammatory processes eaused by other STI pathogens facilitate persistent HPV infection in the cervical epithelium. Among the main etiological agents responsible for STIs that may be potentially involved in cervical carcinogenesis are Ct, HSV 1 and 2, Neisseria Gn, $M g, T v$, and $T p$, which cause inflammatory processes and micro-abrasion or micro-trauma on the cervical epithelium, deteriorating the infection scenario and promoting the persistence of HPV $(78,147)$. Ct has been found repeatedly to associate with CIN/CG in several cross-sectional case-control studies $(148,149)$, although the association has commonly been thought to be the result of confounding by HPV. During recent years, an association with $\mathrm{Ct}$ has also been found in several biobank-based longitudinal studies with invasive CG $(72,150-154)$. A possible explanation for the association of $\mathrm{Ct}$ and CC 
might be that the Ct-induced inflammation results in an impaired ability to clear $H P V$ infections (72).

The hypothesis establishes that the epithelial cells infected by $C t$ become susceptible to infection with $h r-H P V$ and the synergistic actions of the two infectious organisms lead to development of neoplasia $(155,156)$. Persistent and recurrent Chlamydial infection, liberation of cytotoxic substances like nitric oxide as well as anti-apoptotic mechanisms come into play resulting in proliferation of damaged cells and initiating carcinogenesis, the co-factor role of the organism in $H P V$ associated cervical lesions can be attributed to immune-modulation (151). As a result of a disturbances and under the influence of persistent infection, the cells escape of the control of the cell signaling mechanisms, DNA damage occurs leading to proliferation of clones of cells carrying altered genetic material with enhanced propensity for neoplastic change (126). The sites of infection by $C t$ are columnar epithelial cells of the endocervix as is evident by the increased prevalence of infection in cases with cervical ectropion; regions of squamous metaplasia of cervix are increasingly infected by $C t$ for the high prevalence of squamous cell carcinoma in association with the infection $(153,157)$. When CT infects a cell, entry of $H P V$ to the basal layer is facilitated by microscopic epithelial injuries, micro-trauma, or micro-abrasion. HPV viral particles accumulate and derangement of host immunity occurs, which is manifested by shift of the immune response from T-helper cell type 1 (active in $H P V$ control) to T-helper cell type 2 and plasma cell infiltrates (140).

Several authors $(72,76,158,159)$ have reported the relation between $C t$ and $H P V$ infection in the development and evolution of CIN/CC. As it was mentioned before, Ct infection may play a major role in the etiology of CIN/CG by facilitating $h r-H P V$ entrance and persistence. Probably, this is due to the chronic inflammation induced by the bacteria, and to the resistance to cell apop- tosis that persistent $C t$ infections appear to confer. Deluca et al. (158) say that the association between these two agents seems to be more related to a combined potentiation than to the fact that they share a common route of transmission (160). Controversial and discordant information exists on this topic, and since the role of $C t$ in the natural history of $H P V$ infection is not sufficiently clear, this particular issue merits further study (158). Also, Gopalkrishna et al. (159) mentioned that if there is a synergistic effect when both $C t$ and $H P V$ infection are present in comparison with infection of $H P V$ alone during development of cervical cancer and they found a slightly higher rate of chlamydial infection in patients with CC when they are compared with control patients. That indicates that $C t$ may play a role as a co-factor with regard to the pathological aggressiveness of the disease and the $C t$ chronic infection in conjunction with $H P V$ may be a more pertinent factor mediating $\mathrm{CC}$ risk (161). Although a carcinogenic interaction between $C t$ and $H P V$ has not been directly demonstrated, in vitro data show that $C t$ may inhibit cell apoptosis (162), a contributory element for carcinogenesis. Alternatively, inflammatory cytokine responses during a chlamydial infection may produce ROS that might cause DNA damage or modification, providing a mechanistic link between chronic inflammation and malignant transformation (163). Other bacterial or parasitic infections causing chronic inflammation have also been implicated in human cancer, such as Helicobacter pylori with stomach cancer and Schistosoma haematobium with bladder cancer. Smith et al. (161) based on a large number of newly diagnosed CC patients, consistently indicates a potential etiologic role for $C t$ infection as an $H P V$ cofactor in the development of squamous CC.

In a meta-analysis, Zhu et al. (164) found evidences that the chlamydial infection could be one of the risk factor of cervical cancer. Individuals infected with $C t$ have a heightened risk of developing CC. There- 
fore, it is necessary to expand $C t$ infection screening and treat women with $C t$ infection timely, particularly among women at a higher risk of $H P V$ infections. This approach will not only protect against PID and infertility, but potentially also prevent cervical cancer and reduce the incidence of $\mathrm{CC}$.

The questions of which of the two infections, HPV and Ct: 1 .- which of the two infection has to occur first; 2.- if $C t$ infection increases the risk of acquiring $H P V$. Lehtinen et al. (119) found that $C t$ associated relative risk (RR) of developing CIN was statistically significant comparable, both before and after the acquisition of $H P V 16 / 18$, which suggests that the order of the two infections is not important in cervical carcinogenesis. Several cohort studies have indicated that $C t$ exposure increases the tendency for $H P V$ infection to associate an increased risk for CC $(72,140,165,166)$. An analysis of the $H P V$-stratified and $H P V$-adjusted risk estimates obtained both in the univariate and multivariate analyses, suggests that the $C t$ associated RR of developing CIN/CG is comparable both before and after acquisition of $H P V$. Furthermore, no interaction between the two microorganisms was observed. Thus, $C t$ may or could not act in the cervical carcinogenesis by promotion of persistent HPV infection (161). Lehtinen et al. (119) found that $C t$ infection plays an independent cofactor role in the development of cervical neoplasia $(167,168)$, the effect is likely to take place at an early stage of cervical carcinogenesis. Lehtinen et al. (119) mentioned that $C t$ infection might facilitate the development of early cervical lesions. On the other hand, a proportion of CIN lesions regress spontaneously. This and the fact that $C t$ in other longitudinal studies have been associated with early stages of lesions developing cervical cancer suggest that $C t$ may have an early role in cervical carcinogenesis in a proportion of eases. The role of pathobiology is a possible mechanism, however, this remains open $(151,152154,157,169)$.
Anttilla et al. (170) found in a longitudinal sero-epidemiologic study of an association between exposure to specific serotypes or serovars of Ct and CC, especially the squamous (S) histological type. They (170) reported that the presence of serum IgG antibodies to $C t$ serotype or serovar G was associated with the highest risk. Also, immunoglobulin $\mathrm{G}$ antibodies to more than one serotype or serovar of $C t$ increased the risk for subsequent development of SCC. Distribution of the genital serotypes or serovars varies from one geographic area to another, suggesting that some serotypes have biological advantages over others in defined populations (171). Serotypes or serovars D and $\mathrm{E}$ are approximately $50 \%$ of all isolates, followed by $\mathrm{F}$ and $\mathrm{G}$ serotypes or serovars which represent $15 \%$ to $40 \%$; other serotypes or serovars represent less than $10 \%$ each. Serotypes $\mathrm{E}$ and $\mathrm{G}$ have been found more often in women than men, whereas serotype $\mathrm{D}$ has been found more frequently in men than in women (172-176). Lethinen et al. (168) reported that a pool of GFK serotypes or serovars was more common found in patients with SCC than in control women.

Barnes et al. (177) mentioned that the presence of mixed infections implies that infection with one serotype does not induce protective immunity against subsequent infections caused by another serotype or serovar. Antilla et al. (170) reported that multiple exposures might increase the risk of acquiring infections caused by the cancerassociated serotypes. Therefore, antibodies to multiple serotypes detected in patients with cervical SCC may also suggest chronic infection by a single serotype but they could not distinguish between both possibilities.

Finally, a carcinogenic interaction between $C t$ and $H P V$ has not been directly demonstrated, in vitro data show that $C t$ may inhibit cell apoptosis $(161,178)$, a contributory element for carcinogenesis. Alternatively, inflammatory cytokine responses during a chlamydial infection may produce 
ROS that might cause DNA damage or modification, providing a mechanistic link between chronic inflammation and malignant transformation (163).

\section{CONCLUSION}

Further epidemiological studies are needed to clarify the role of $\mathrm{Ct}$ in the etiology of CC. Additional prospective data are needed on the induction of inflammation by $C t$ and other STIs and on the effect of their relative timing, in conjunction with $H P V$ infection, on the risk of eervical neoplasia, in addition to the effect of the treatment of $\mathrm{Ct}$ infection on the progression of cervical neoplasia. Studies on a large number of newly diagnosed CC patients, consistently indicate a potential etiologic role for $C t$ infection as an HPV cofactor in the development of squamous CC (161). Beyond potentially aiding the establishment or progression of HPV infections, different authors $(120,170)$ speculate that the inflammatory response and metaplasia triggered by $C t$ infection may encourage cell turnover and therefore the number of non-dividing differentiating cells that are needed for $H P V$ replication and productive $H P V$ infections. Further, persistent $C t$ infections may create an inflammatory environment conductive to $H P V$-induced carcinogenesis by increasing the chance of DNA replication errors that have been shown in vitro to lead to persistent disease and accumulation of genetically damaged cells.

As it is well known that, the development of CC takes several years or decades. The link between bacterial infections and carcinogenesis is not clear, but genetic damage and neoplastic changes can be induced in vitro by coculturing cells with activated inflammatory cells (179). As it was mentioned before in the manuscript, during a $C t$ infection, nitric oxide is released (1) and is able to inhibit host cell apoptosis (178). In a chronic chlamydial infections, these mechanisms could initiate or promote cervical carcinogenesis. The fact that the exposure to a specific serotype or to more than one serotype or serovar increases the evidence for the role of $C t$ in cervical carcinogenesis by itself (170).

Future and further studies should address the question of whether Ct plays as a co-factor role or as an independent factor role in the carcinogenesis of CC; this effect is likely to take place at an early stage of cervical carcinogenesis and/or restricted to some cases only.

\section{REFERENCES}

1. O'Connell CM, Ferone ME. Chlamydia trachomatis genital Infections. Microb Cell. 2016;3(9):390-403. doi:10.15698/ mic 2016. 09.525 .

2. BéBéar C, de Barbe B. Genital Chlamydia trachomatis infections. Clin Microbien Infect 2009:15(1):4-10.

3. Workowski KA, Bolan GA. Centers for Disease Control and Prevention. Sexually transmitted diseases treatment guidelines, 2015. MMWR Recomm Rep. 2015 Jun 5;64(RR-03):1-137. Erratum in: MMWR Recomm Rep 2015 Aug 28;64(33):924.

4. Rowley J, Vander Hoorn S, Korenromp E, Low N, Unemo M, Abu-Raddad LJ, Chico RM, Smolak A, Newman L, Gottlieb S, Thwin SS, Broutet N, Taylor MM. Chlamydia, gonorrhoea, trichomoniasis and syphilis: global prevalence and incidence estimates, 2016. Bull World Health Organ. 2019 1;97(8):548-562. doi: 10.2471/ BLT.18.228486. Epub 2019 Jun 6.

5. Redmond SM, Alexander-Kisslig K, Woodhall SC, van den Broek IVF, van Bergen J, Ward H, Uusküla A, Herrmann B, Andersen B, Götz HM, Sfeteu O, Low N. Genital chlamydia prevalence in European non-European high income countries: systematic review and meta-analysis. PLoS One 2015;10(1):e0115753. doi:10.1371/ journal.pone.0115753.

6. Núñez-Troconis J, Gallegos B, Noriega C. Incidencia de la Chlamydia trachomatis en pacientes con esterilidad. Invest. Clin 1990;31(2): 91-104.

7. Núñez-Troconis J. Investigación de tres patógenos de transmisión sexual en diferentes patologías ginecológicas. Rev Obstet Ginecol Venez 1998;58(3):175-185. 
8. Vivas K, Albarracin L, Ruiz E, Téllez, Moreno Y, Noguera MU, Monsalve N, Mendoza JA. Infección por virus del papiloma humano y Chlamydia trachomatis y su implicación en el desarrollo de las lesiones cervicales en mujeres de la ciudad de Mérida. Rev Obstet Ginecol. 2018:78(2):113-121.

9. Albritton HL, Kozlowski PA, Lillis RA, MeGowan Cl, Siren D, Taylor SN, Ibana JA, Buckner LR, Shen L, Quayle AJ. A novel whole-bacterial enzyme linkedimmunosorbant assay to quantify Chlamydia trachomatis specific antibodies reveals distinct differences between systemic and genital compartments. PLoS One. 2017;12(8):e0183101. doi: 10.1371/journal.pone.0183101

10. Molano M, Weiderpass E, Posso H, Morré SA, Ronderos M, Franceschi S, Arsian A, Meijer CJLM, Miñoz N, van den Brule AJC, HPV study group. Prevalence and determinants of Chlamydia trachomatis infections in women from Bogota, Colombia. Sex Transm Infect. 2003;79(6):474-478. doi:10.1136/sti.79.6.474.

11. Malhotra M, Sood S, Mukherjee A, Muralidhar S, Bala M. Genital Chlamydia trachomatis: an update. Indian J Med Res. 2013 Sep;138(3):303-316. PMID: 24135174; PMCID: PMC3818592.

12. Ward ME, Ridgoway G. Chlamydia. In: Collier L, Balows A, Sussman A editors. Topley and Wilsons Microbiology and microbiology infection. $9^{\text {th }}$ edition. New York Press Inc. 1999. p. 1331-1336.

13. Novak M, Novak D. Risk factors for Chlamydia trachomatis infection among users of an internet-based testing service in Sweeden. Sex Reprod Health 2013; 4: 23-27.

14. Stamm WE, Batteiger BE. Chlamydia trachomatis (Trachoma, Perinatal Infections, Lymphogranuloma Venerum and other Genital Infections). 7 th edition. Mandell GL, Bennett JE, Dolin R, editors. Philadelphia: Churchill Livingstone Elsevier; 2010.

15. Wyrick PB. Chlamydia trachomatis persistence in vitro: An overview. J Infect Dis. 2010; 201 Suppl 2: S88-S95. Epub 2010 May 28.

16. Lambden PR, Pickett MA, Clarke IN. The effect of penicillin on Chlamydia trachomatis DNA replication. Microbiol 2006; 152(Pt 9): 2573- 2578.
17. Elwell C, Mirrashidi K, Engel J. Chlamydia cell biology and pathogenesis. Nat Rev Microbiol. 2016;14(6):385-400. doi: 10.1038/ nrmicro.2016.30. Epub 2016 Apr 25. PMID: 27108705 ; PMCID: PMC4886739.

18. Hussen $\mathrm{S}$, Wachamo $\mathrm{D}$, Yohannes $\mathrm{Z}$, Tadesse E. Prevalence of Chlamydia trachomatis infection among reproductive age women in sub Saharan Africa: a systematic review and meta-analysis. BMC Infect Dis. 2018;18(1):596. doi:10.1186/s12879-0183477.

19. Rogstad K. Complications in the female and their management. In: Moss T, ed. International handbook of Chlamydia, 3rd edition. Haslemere, UK: Alden Press, 2008; p. 111-121.

20. Peipert JF. Clinical practice. Genital chlamydial infections. N Engl J Med 2003; 349: 2424-2430.

21. Paavonen J, Eggert-Kruse W. Chlamydia trachomatis: impact on human reproduction. Hum Reprod Update 1999; 5: 433447.

22. Hicks D. Complications of Chlamydia trachomatis infection in men. In: Moss TR, ed. International handbook of Chlamydia, 3rd edition. Haslemere, UK: Alden Press, 2008; p. 99-109.

23. Barbeyrac de B, Papaxanthos Roche A, Mathieu C, Germain C, Brun JL, Gachet M, Mayer G, Bébéar C, Chene G, Hock C. Chlamydia trachomatis in subfertile couples undergoing an in vitro fertilization program: a prospective study. Eur J Obstet Gynecol Reprod Biol 2006; 129: 46-53. PMID: 16701936 doi: 10.1016/j.ejogrb.2006.02.014.

24. Malinverni R. The role of cytokines in chlamydial infections. Curr Opin Infect Dis 1996; 9: 150-155.

25. Morton RS, Kinghorn GR. Genitourinary chlamydial infection: a reappraisal and hypothesis. Int J STD AIDS 1999; 10 : 765-75.

26. Rasmussen SJ, Eckmann L, Quayle AJ, Shen L, Zhang Y, Anderson DJ, Fierer J, Stephens RS, Kagnoff MF. Secretion of pro-inflammatory cytokines by epithelial cells in response to Chlamydial infection suggests a central role for epithelial cells in chlamydial pathogenesis. J Clin Invest 1997; 99: 77-87. 
27. Morrison SG, Morrison RP. A predominant role of antibody in acquired immunity to chlamydial genital tract reinfection. J Immunol 2005; 73: 6183-6186.

28. Haggerty CL, Gottlieb SL, Taylor BD, Low N, Xu F, Ness RB. Risk of sequelae after Chlamydia trachomatis genital infection in women. J Infect Dis 2010; 201 (Suppl 2): S134-S155.

29. Zdrodowska-Stefanow B, OstaszewskaPuchalska I, Pucilo K. The immunology of Chlamydia trachomatis Arch Immunol Ther Exp 2003; 51: 289-294.

30. Burstein GR, Gaydos CA, Diener-West M. Incidence of Chlamydia trachomatis infection among inner-city adolescents. JAMA 1998; 280: 521-526.

31. Thompson PA, Khatami M, Baglole CJ, Sun J, Harris SA, Moon EY, Al-Mulla F, AlTemaimi R, Brown DG, Colacei A, Mondello C, Raju J, Ryan EP, Woodrick J, Scovassi AI, Singh N, Vaccari M, Roy R, Forte S, Memeo L, Salem HK, Amedei A, Hamid RA, Lowe L, Guarnieri T, Bisson WH. Environmental immune disruptors, inflammation and cancer risk. Carcinogenesis. 2015;36(Suppl 1):S232-S253. doi: 10.1093/carcin/bgv038. PMID: 26106141; PMCID: PMC4492068.

32. Khatami, M. Chronic inflammation: synergistic interactions of recruiting macrophages (TAMs) and eosinophils (Eos) with host mast cells (MCs) and tumorigenesis in CALTs. M-CSF, suitable biomarker for cancer diaǵnosis! Cancers (Basel) 2014;6:297-322.

33. Colotta F, Allavena P, Sica A, Garlanda C, Mantivani A. Cancer-related inflammation, the seventh hallmark of cancer: links to genetic instability. Carcinogenesis 2009;30:1073-1081.

34. Hanahan, D, Weinberg RA. The hallmarks of cancer: the next generation. Cell 2000; 100:57-70.

35. Khatami, M. 'Yin and Yang' in inflammation: duality in innate immune cell function and tumorigenesis. Expert Opin. Biol. Ther 2008;8:1461-1472.

36. Candido J, Hageman T. Cancer-related inflammation. J. Clin. Immunol 2013;33 (suppl. 1): S79-S84.

37. Costa A, Scholer-Dahirel A, Mecha-Gregoriou $\mathrm{F}$. The role of reactive oxygen species and metabolism on cancer cells and their microenvironment. Semin. Cancer Biol 2014;25: 23-32.

38. Khatami M. Unresolved inflammation: 'immune tsunami' or erosion of integrity in immune-privileged and immune-responsive tissues and acute and chroniinflammatory diseases or cancer. Expert Opin. Biol. Ther 2011;11:1419-1432.

39. Roberts RA, Smith RA, Safe S, Szabo C, Tjalkens RB, Robertson FM.. Toxicological and pathophysiological roles of reactive oxyǵen and nitrogen species. Toxicology 2010;276:85-94.

40. Naik E, Dixit VM. Mitochondrial reactive oxygen species drive proinflammatory cytokine production. J. Exp. Med 20111;208(3):417-420.

41. Kongara S, Karantza V. The interplay between autophaǵy and ROS in tumorigenesis. Front Oncol. 2012 Nov 21;2:171. doi: 10.3389/fonc.2012.00171. PMID: 23181220; PMCID: PMC3502876.

42. Danelli L, Frossi B, Sri G, Mion F, Guarnotta L, Tripodo C, Marluzzi L, Marzinotto S, Rigoni A, Blank U, Colombo MP, Pucillo CE. Mast cells boost myeloidderived suppressor cell activity and contribute to the development of tumor-favoring microenvironment. Cancer Immunol. Res. 2015;3(1):85-95. doi: 10.1158/2326-6066. CIR-14-0102. Epub 2014 Oct 28.

43. Grimm EA, Sikora AG, Ekmekcioglu S. Molecular pathways: inflammationassociated nitric-oxide production as a cancer-supporting redox mechanism and a potential therapeutic target. Clin Cancer Res 2013;19(20):5557-5563. doi: 10. 1158/1078-0432.CCR-12-1554.

44. Moran EM. Epidemiological and clinical aspects of nonsteroidal anti-inflammatory drugs and cancer risks. J. Environ. Pathol. Toxicol. Oncol 2002;21:193-201.

45. Wakabayashi K. NSAIDs as cancer preventive aǵents. Asian Pac. J. Cancer Prev 2000:1:97-113.

46. Baglole CJ, Ray DM, Bernstein SH, Feldon SE, Smith TJ, Sime PJ, Phipps RP. More than structural cells, fibroblasts create and orchestrate the tumor microenvironment. Immunol. Invest. 2006;35(3-4):297-325. doi: 10.1080/08820130600754960. 
47. Nataraj C, Thomas DW, Tilley SL, Nguyen MT, Mannon R, Koller BH, Coffman YM. Receptors for prostaglandin E2 that regulate cellular immune responses in the mouse. J. Clin. Invest. 2001;108(8):1229-1235. doi: 10.1172/JCI13640.

48. Tilley SL, Coffman TM, Koller BH. Mixed messages: modulation of inflammation and immune responses by prostaǵlandins and thromboxanes. J Clin Invest 2001;108(1):15-23. doi:10.1172/JCI1341.

49. Zhu Z, Zhong S, Shen $Z$. Targeting the inflammatory pathways to enhance chemotherapy of cancer. Cancer Biol Ther 2011;12(2):95-105. doi:10.4161/cbt. 12.2. 15952 .

50. Bollrath J, Greten FR. IKK/NF-kappaB and STAT3 pathways: central siǵnalling hubs in inflammation-mediated tumour promotion and metastasis. EMBO Rep 2009;10(12):1314-1319. doi:10.1038/embor.2009.243.

51. Nguyen DP, Li J, Tewari AK. Inflammation and prostate cancer: the role of interleukin 6 (IL-6). BJU Int 2014;113(6):986-992. doi:10.1111/bju.12452.

52. Zhang HF, Lai R. STAT3 in Cancer-Friend or Foe? Cancers (Basel) 2014;6(3):14081440. doi:10.3390/cancers6031408.

53. He G, Karin M. NF- $\kappa$ B and STAT3 - key players in liver inflammation and cancer. Cell Res 2011;21(1):159-168. doi:10.1038/cr. 2010.183

54. Feldmann M, Maini SR. Role of eytokines in rheumatoid arthritis: an education in pathophysiology and therapeutics. Immunol Rev 2008; 223:7-19. doi:10.1111/ j.1600-065X.2008.00626.x

55. Croft M. The TNF family in T cell differentiation and function--unanswered questions and future directions. Semin Immunol 2014;26(3):183-190. doi:10.1016/j.smim. 2014.02.005.

56. Ataie-Kachoie P, Pourgholami MH, Richardson DR, Morris DL. Gene of the month: Interleukin 6 (IL-6). J Clin Pathol 2014;67(11):932-937. doi:10.1136 jclinpath-2014-202493.

57. Rose-John S, Scheller J, Elson G, Jones SA. Interleukin-6 biology is coordinated by membrane-bound and soluble receptors: role in inflammation and cancer. J Leukoc
Biol 2006;80(2):227-236. doi:10.1189/jlb. 1105674.

58. Taniguchi K, Karin M. IL-6 and related cytokines as the critical lynchpins between inflammation and cancer. Semin Immunol 2014;26(1):54-74. doi:10.1016j. smim.2014.01.001.

59. Tsukamoto H, Nishikata R, Senju S, Nishimura Y. Myeloid-derived suppressor cells attenuate TH1 development through IL-6 production to promote tumor progression. Cancer Immunol Res 2013;1(1):6476. doi:10.1158/2326-6066.CIR-13-0030.

60. Zarogoulidis P, Katsikogianni F, Tsiouda T, Sakkas A, Katsikogiannis N, Zarogoulidis K. Interleukin-8 and interleukin-17 for cancer. Cancer Invest 2014;32(5):197-205. doi: 10.3109/07357907.2014.898156.

61. Campbell LM, Maxwell PJ, Waugh DJ. Rationale and Means to Target Pro-Inflammatory Interleukin-8 (CXCL8) Siǵnaling in Cancer. Pharmaceuticals (Basel) 2013; 6(8):929-59. doi: 10.3390/ph6080929. PMID: 24276377 ; PMCID: PMC3817732.

62. Schneider C, Pozzi A. Cyclooxyǵenases and lipoxygenases in cancer. Cancer Metastasis Rev 2011; 30(3-4):277-94. doi: 10.1007/ s10555-011-9310-3. PMID: 22002716; PMCID: PMC3798028.

63. Greene ER, Huang S, Serhan CN, Panigrahy D. Regulation of inflammation in cancer by eicosanoids. Prostaglandins Other Lipid Mediat 2011;96(1-4):27-36. doi: 10.1016/j.prostaǵlandins.2011.08.004. Epub 2011 Aug 16. PMID: 21864702; PMCID: PMC4051344.

64. Bishayee K, Khuda-Bukhsh AR. 5-lipoxygenase antagonist therapy: a new approach towards targeted cancer chemotherapy. Acta Biochim Biophys Sin (Shanghai). 2013;45(9):709-719. doi: 10.1093/abbs/ gmt064.

65. Gilmartin AG, Faith TH, Ritcher M, Groy A, Seefeld MA, Darey MG, Peng X, Federowiez K, Yang J, Zhang SY, Minthon E, Jaworski JP, Schaber M, Marlens S, McNully DE, Sinnamon RH, Zhang H, Kirkpatrick RB, Nevins N, Cui G, Pietrak B, Diaz E, Jones A, Brandt M, Schwartz B, Heerding DA, Kumar R. Allosteric Wip1 phosphatase inhibition through flap subdomain interaction. Nat. Chem. Biol 2014;10(3):181-187. 
doi: 10.1038/nchembio.1427. Epub 2014 Jan 5.

66. Datta K, Biswal SS, Kehrer JP. The 5-lipoxygenase-activating protein (FLAP) inhibitor, MK886, induces apoptosis independently of FLAP. Biochem J 1999;340 (Pt 2) (Pt 2):371-375. PMID: 10333477; PMCID: PMC1220259.

67. Schuller HM, Zhang L, Weddle DL, Castonguay A, Walker K, Miller MS. The cyclooxygenase inhibitor ibuprofen and the FLAP inhibitor MK886 inhibit pancreatic carcinogenesis induced in hamsters by transplacental exposure to ethanol and the tobaceo carcinogen NNK. J Cancer Res Clin Oncol 2002;128(10):525-532. doi:10.1007/ s00432-002-0365-y

68. International Agency for Research on Cancer. World Health Organization. Cancer 2018 Available at: https://gco.iare.fr/ today/data/factsheets/populations/900world-fact-sheets.pdf. Consulted on 06/20/2020.

69. Pan-American Health Organization. Cáncer Cervicouterino 2018. Available at: https:// www.paho.org/hq/index.php?option $=\mathrm{com}$ content $\&$ view $=$ article $\&$ id $=5420: 2018$ cervical-cancer $\&$ Itemid $=3637 \&$ lang $=$ es. Consultred on: 06/20/2020.

70. Smith JS, Bosetti C, Munoz N, Herrero R, Bosch FX, Eluf-Neto J, Meijer CJ, Van Den Brule AJ, Franceschi S, Peeling RW. Chlamydia trachomatis and invasive cervical cancer: A pooled analysis of the IARC multicentric case-control study. Int J Cancer 2004;111: 431-439.

71. Schachter J, Hill EC, King EB, Coleman VR, Jones P, Meyer KF. Chlamydial infection in women with cervical dysplasia. Am J Obstet Gynecol 1975;123:753-757.

72. Silins I, Ryd W, Strand A, Wadell G, Tomberg $\mathrm{S}$, Hansson BG, Wang $\mathrm{X}$, Arnheim L, Dahl L, Dahl V, Brenell D, Parson K, Diener J, Rylander E. Chlamydia trachomatis infection and persistence of human papillomavirus. Int J Cancer 2005;116(1):110115. doi:10.1002/ijc.20970.

73. Murta EFC, de Souza MAH, Adad SJ, Araúijo Jr E. Infecção pelo papilomavírus humano em adolescentes: relação com o método anticoncepcional, gravidez, fumo e achados citológicos. Rev Bras Ginecol Obstet 2001;23: 217-221.

74. Martins MCL, Bôer CG, Svidzinski TIE, Estivalet TI, Donida LG, Martins PFA, Boscoli FNS, Consolaro MEL. Avaliação do método de Papanicolaou para triagem de algumas infecȩões cérvico-vaǵinais. Rev Bras Anal Clin 2007;39: 217-221.

75. Campos ACC, Freitas-Júnior R, Ribeiro LFJ, Paulinelli RR, Reis C. Prevalence of vulvovaginitis and bacterial vaginosis in patients with koilocytosis. Sao Paulo Med J 2008;126: 333-336.

76. Wohlmeister D, Vianna DR, Helfer VE, Gimenes F, Consolaro ME, Barcellos RB, Rossetti ML, Calil LN, Buffon A, Pilger DA. Association of human papillomavirus and Chlamydia trachomatis with intraepithelial alterations in cervix samples. Mem Inst Oswaldo Cruz 2016 Feb;111(2):106113. doi: 10.1590/0074-02760150330. Epub 2016 Feb 2. PMID: 26841046; PMCID: PMC4750450.

77. Muvunyi CM, Dhont N, Verhelst R, Crueitti T, Reijans M, Mulders B, Simons G, Temmerman M, Claeys G, Padalko E. Evaluation of a new multiplex polymerase chain reaction assay STDFinder for the simultaneous detection of 7 sexually transmitted disease pathogens. Diagn Microbiol Infect Dis 2011; 71: 29-37.

78. Rodríguez-Cerdeira C, Sánchez-Blanco E, Alba A. Evaluation of association between vaginal infections and high-risk human papillomavirus types in female sex workers in Spain. ISRN Obstet Gynecol 2012: 240190. doi:10.5402/2012/240190.

79. Reddy BS, Rastogi S, Das B, Salhan S, Verma S, Mittal A. Cytokine expression pattern in the genital tract of Chlamydia trachomatis positive infertile women - implication for T-cell responses. Clin Exp Immunol 2004;137(3):552-558. doi:10.1111/ j.1365-2249.2004.02564.x

80. Pal S, Hui W, Peterson EM, de la Maza LM. Factors influencing the induction of infertility in a mouse model of Chlamydia trachomatis ascending genital tract infection. J Med Microbiol 1998; 47:599-605.

81. Brunham RC. Human immunity to chlamydiae. In: Stephens RS, ed. Chlamydia: 
Intracellular Biology, Pathogenesis and Immunity. Washington DC: ASM Press, 1999; 211-238.

82. Igietseme JU, Uriri IM, Kumar SN, Anaqnaba GA, Ojior OO, Momodu IA, Caudal DH, Black CM. Route of infection that induces a high intensity of gamma interferonsecreting T-cells in the genital tract produces optimal protection against Chlamydia trachomatis infection in mice. Infect Immun 1998; 66:4030-4035.

83. Kelly KA, Robinson E, Rank RG. Initial route of antigen administration alters the T-cell cytokine profile produced in response to the mouse pneumonitis biovar of Chlamydia trachomatis following genital infection. Infect Immun 1996; 64:4976-4983.

84. Kelly KA 2, Walker JC, Jameel SH, Gray HL, Rank RG. Differential regulation of CD4 lymphocyte recruitment between the upper and lower regions of the genital tract during Chlamydia trachomatis infection. Infect Immun 2000; 68:1519-1528.

85. Rank RG, Bowlin AK, Kelly KA. Characterization of lymphocyte response in the female genital tract during ascending chlamydial genital infection in the guinea pig model. Infect Immun 2000; 68:5293-5298.

86. Openshaw P, Murphy EE, Hosken NA, Maine V, Davis K, Murphy K, O’Garra. Heterogeneity of intracellular cytokine synthesis at the single cell level in polarized T helper1 and T helper-2 populations. J Exp Med 1995; 182:1357-1367.

87. Arno JN, Ricker VA, Batteiger BE. Interferon-g in endocervical secretions of women infected with Chlamydia trachomatis. J Infect Dis 1990; 162:1385-1389.

88. Rank RG, Ramsey KH, Pack EA, Williams DM. Effect of gamma interferon on resolution of murine chlamydial genital infection. Infect Immun 1992; 60:4427-4429.

89. Zhong G, Peterson EM, Czarniecki CW, Schreiber RD, de la Maza LM. Role of endoǵenous gamma interferon in host defense aǵainst Chlamydia trachomatis infections. Infect Immun 1989; 57:152-157.

90. Perry LL, Feilzer K, Caldwell HD. Immunity to Chlamydia trachomatis is mediated by T-helper 1 cells through IFN-gamma-dependent and independent pathways. J Immunol 1997; 158:3344-3352.
91. Beatty WL, Byrne GI, Morrison RP. Morphologic and antigenic characterization of interferon-gamma mediated persistent Chlamydia trachomatis infection in vitro. Proc Natl Acad Sci USA 1993; 90:39984002.

92. Rottenberg ME, Gigliotti-Rothfuchs A, Wigzell H. The role of IFN-gamma in the outcome of chlamydial infection. Curr Opin Immunol 2002; 14:444-451.

93. Durum SK, Schimidt JA, Oppenheim JJ. Interleukin-1: An immunological perspective. Ann Rev Immunol 1985; 3:263-287.

94. MittalA,KapurS,GuptaS. Host Immuneresponse in chlamydial cervicitis. Br J Biomed Sci 1996; 53:941-947.

95. Kelly KA. Cellular immunity and Chlamydia genital infection: Induction, recruitment and effector mechanisms. Int Rev Immunol 2003; 22:3-41. doi: 10.1080/08830180305229.

96. Tseng CK, Rank RG. Role of NK cells in early host immune response to chlamydial genital infection. Infect Immun 1998; 66:5867-5875.

97. Stagg AJ, Elsley WAJ, Holland MJ. Dendritic cells (DC) in the initiation of immune responses to Chlamydia. In: Mardh PA, La Placa M, Ward ME, eds. Proceedings Of European Society for Chlamydia Research. Town: Publisher, 1992: p.77-80.

98. Conti P, Kempuraj D, Kandere K, Di Gioacchino M, Barbacane RC, Castellani ML, Felaco M, Bouchr W, Letourneau R, Theoharides TC. IL-10, an inflammatory/ inhib- itory cytokine, but not always. Immunol Lett 2003; 86:123-129. doi: 10.1016/ s0165-2478(03)00002-6.

99. Campbell K. Understanding how viruses can cause malignant disease. Nurs Times 2006; 102:30-31.

100. Campbell K. The infectious causes of cancer. Nurs Times 2006;102:28-30.

101. Ledwaba T, Dlamini $Z$, Naicker S, Bhoola K. Molecular genetics of human cervical cancer: role of papillomavirus and the apoptotic cascade. Biol Chem 2004;385:671682.

102. Nahar A, Azad AK. Sexually transmitted diseases (STD) / reproductive tract infections (RTI) including acquired immunodeficiency syndrome (AIDS) / human immuno- 
deficiency virus (HIV) infections among the women of reproductive age group: a review. J Prev Soc Med 1999;18:84-88.

103. Thomas DJ. Sexually transmitted viral infections: epidemiology and treatment. J Obstet Gynecol Neonatal Nurs 2001;30:316323.

104. Kanodia S, Fahey LM, Kast WM. Mechanisms used by human papillomaviruses to escape the host immune response. Curr Cancer Drug Targets 2007;7:79-89.

105. Klein E, Kis LL and Takahara M. Pathogenesis of Epstein-Barr virus (EBV)-carrying lymphomas. Acta Microbiol Immunol Hung 2006;53:441- 457.

106. Negro F. Mechanisms and significance of liver steatosis in hepatitis $C$ virus infection. World J Gastroenterol 2006;12:6756-6765.

107. Moss SF, Blaser MJ. Mechanisms of disease: Inflammation and the origins of eancer. Nat Clin Pract Oncol 2005;2:90-97.

108. Rapp F. Current knowledge of mechanisms of viral carcinogenesis. Crit Rev Toxicol 1984; 13:197-204.

109. Willecke K, Schafer R. Human oncogenes. Hum Genet 1984;66:132-142.

110. Gilden RV, Rabin H. Mechanisms of viral tumorigenesis. Adv Virus Res 1982;27:281334.

111. Cuschieri KS, Horne AW, Szarewski A, Cubie HA. Public awareness of human papillomavirus. J Med Screen 2006;13:201- 207.

112. Behtash N, Mehrdad N. Cervical eancer: screening and prevention. Asian Pac J Cancer Prev 2006;7:683-686.

113. Dehn D, Torkko KC, Shroyer KR. Human papillomavirus testing and molecular markers of cervical dysplasia and carcinoma. Cancer 2007;111:1-14.

114. Weaver BA. Epidemiology and natural history of genital human papillomavirus infection. J Am Osteopath Assoc 2006;106:S2-8.

115. Zheng ZM, Baker CC. Papillomavirus genome structure, expression, and post-transcriptional regulation. Front Biosei 2006; 11:2286-2302.

116. Monsonego J. Cervical cancer prevention: the impact of $H P V$ vaceination. Gynecol Obstet Fertil 2006;34:189-201.

117. Malik AI. The role of human papilloma virus (HPV) in the aetiology of cervical cancer. J Pak Med Assoc 2005;55:553-558.
118. Trottier H, Franco EL. The epidemiology of genital human papillomavirus infection. Vaccine 2006;24:S1-1S5.

119. González-Martinez G, Núñez-Troconis $J$. Historia natural de la infección por el virus del papiloma humano: una actualización. Invest Clin 2014;55(1):82-91.

120. Lehtinen M, Ault KA, Lyytikainen E, Dillner J, Garland SM, Ferris DG, Koutsky LA, Sings HL, Lu S, Haupt RM, Paavonen J; FUTURE I and II Study Group. Chlamydia trachomatis infection and risk of cervical intraepithelial neoplasia. Sex Transm Infect 2011 Aug;87(5):372-6. doi: 10.1136/ sti.2010.044354. Epub 2011 Apr 6. PMID: 21471141 ; PMCID: PMC3252607.

121. Madeleine MM, Anttila T, Schwartz SM, Saikku P, Leinonen M, Carter JJ, Wurscher M, Johnson LG, Galloway DA, Daling JR. Risk of cervical cancer associated with Chlamydia trachomatis antibodies by histology, $H P V$ type and $H P V$ cofactors. Int J Cancer 2007;120(3):650-655. doi: 10.1002/ijc.22325. PMID: 17096345; PMCID: PMC4049152.

122. Muñoz N, Bosch FX, de Sanjosé S, Herrero R, Castellsagué X, Shah K, Snijders PJF, Meijer CJLM, International Agency for Research on Cancer, Mukticenter Cervical Cancer Study Group. Epidemiologic classification of human papillomavirus types associated with cervical cancer. N Engl J Med 2003;348(6):518-527. doi:10.1056/NEJMoa021641.

123. Gravitt PE, Castle PE. Chlamydia trachomatis and cervical squamous cell carcinoma. JAMA 2001;285:1703-1704.

124. Al-Daraji WI, Smith JH. Infection and cervical neoplasia: facts and fiction. Int $\mathrm{J}$ Clin Exp Pathol 2009;2(1):48-64.

125. Fullgrabe J, Kavanagh E, Joseph B. Histone onco-modifications. Oncogene 2011;30: 3391-3403.

126. Clayton AL, Mahadevan LC. MAP kinasemediated phosphoacetylation of histone $\mathrm{H} 3$ and inducible gene regulation. FEBS Lett 2003;546, 51-58.

127. Chumduri C, Gurumurthy RK, Zadora PK, Mi Y, Meyer TF. Chlamydia infection promotes host DNA damage and proliferation but impairs the DNA damage response. Cell Host Microbe 2013;13(6):746-758. doi:10.1016/j.chom.2013.05.010 
128. Pennini ME, Perrinet S, Dautry-Varsat A, Subtil A. Histone methylation by NUE, a novel nuclear effector of the intracellular pathogen Chlamydia trachomatis. PLoS Pathog 2010;6, e1000995.

129. Miller KM, Jackson SP. Histone marks: repairing DNA breaks within the context of chromatin. Biochem. Soc. Trans 2012; 40: 370-376.

130. O'Driscoll M, Jeǵgo A. The role of doublestrand break repair- insights from human genetics. Nat. Rev. Genet 2006;7: 45-54.

131. Lebreton A, Lakisic G, Job V, Fritsch L, Tham TN, Camejo A, Matteı PJ, Regnault B, Nahori MA, Cabanes D, Gautreau A, Ait-Si-Ali S, Dessen A, Cossart P, Bierne H. A bacterial protein targets the BAHD1 chromatin complex to stimulate type III interferon response. Science 2001; 331:1319-1321.

132. Fehri LF, Rechner C, Janssen S, Mak TN, Holland C, Bartfeld S, Brugigemann H, Meyer FM. Helicobacter pylori induced modification of the histone H3 phosphorylation status in gastric epithelial cells reflects its impact on cell cycle regulation. Epigenetics 2009; 4: 577-586.

133. Fernandez-Capetillo $\mathrm{O}$, Allis CD, Nussenzweig A. Phosphorylation of histone $\mathrm{H} 2 \mathrm{~B}$ at DNA double-strand breaks. J. Exp. Med 2004; 199:1671-1677.

134. Utley RT, Lacoste N, Jobin-Robitaille O, Allard S, Coté J. Regulation of NuA4 histone acetyltransferase activity in transcription and DNA repair by phosphorylation of histone $\mathrm{H} 4$. Mol. Cell. Biol 2005;25: 8179-8190.

135. Tjeertes JV, Miller KM, Jackson SP. Screen for DNA-damage- responsive histone modifications identifies H3K9Ac and H3K56Ac in human cells. EMBO J 2009;28;1878-1889.

136. Paavonen J, Purola E. Cytologic findings in cervical chlamydial infection. Med Biol 1980;58(3):174-178.

137. Luostarinen $T$, Lehtinen $M$, Bjorge $T$, Abeler V, Hakana M, Hellman's G, Jellum E, Koskela T, Lenner P, Lie AK, Paavonen J, Pukkala E, Saikku P, Sigstad E, Thoresen $\mathrm{S}$, Thoresen $\mathrm{S}$, Yuongman LD, Diller J, Hakulinen T. Joint effects of different human papillomaviruses and Chlamydia trachomatis infections on risk of squamous cell carcinoma of the cervix uteri. Eur J Cancer 2004;40:1058e65.

138. Arnheim L. Immunological Responses in Genital HPV Infections and Etiology of Cervical Cancer. Stockholm, Sweden: Karolinska Institute, 2005:1e75. Available http:// diss. kib.ki.se/2005/91-7140-266-7/thesis. pdf. Accesed on: June 10, 2020.

139. Quint KD, de Koning MN, Geraets DT, Quint WG, Pirog EC. Comprehensive analysis of Human Papillomavirus and Chlamydia trachomatis in in-situ and invasive cervical adenocarcinoma. Gynecol Oncol 2009;114(3):390-394. doi:10.1016/j.ygyno.2009.05.013

140. Agrawal T, Vats V, Wallace L. Role of cervical dendritic cell subsets, co-stimulatory molecules, cytokine secretion profile and beta-estradiol in development of sequalae to Chlamydia trachomatis infection. BMC Reproduct Biol Endocrinol 2008;6:46.

141. Samoff E, Koumans EH, Markowitz LE, Sternberg M, Sawyer MK, Swan D, Papp JR, Black CM, Unger ER. Association of Chlamydia trachomatis with persistence of high-risk types of human papillomavirus in a cohort of female adolescents. Am J Epidemiol 2005;162(7):668-675. doi: 10.1093/ aje/kwi262. Epub 2005 Aug 24.

142. Stamm WE. Chlamydia trachomatis infections of the adult. In: Holmes KK, Mardh PA, Sparlin PF, Lemon SM, Stamm WE, Piot P, Wasserheit JN, editors. Sexually transmitted diseases, 3rd edition. New York: McGraw-Hill, 1999. p:407-422.

143. Nobbenhuis MA, Walboomers JM, Helmerhorst TJ, Rozendaal L, Remmink AJ, Risse EK, van der Linden HC, Voorhorst FJ, Kenemans P, Meijer CJ. Relation of human papillomavirus status to cervical lesions and consequences for cervical-cancer screening: a prospective study. Lancet 1999; 354:20-25.

144. Kjaer SK, van den Brule AJ, Paull G, Svare EI, Sherman ME, Thomsen BL, Suntum M, Bock JE, Poll PA, Meijer CJ. Type specific persistence of high risk human papillomavirus $(H P V)$ as indicator of high grade cervical squamous intraepithelial lesions in young women: population based prospective follow up study. BMJ 2002; 325:572. 
145. Schiffman M, Solomon D. Cervical-cancer screening with human papillomavirus and cytologic co-testing. New Enǵl J Med 2013;369: 2324-2331.

146. Martins MCL, Bôer CG, Svidzinski TIE, Estivalet TI, Donida LG, Martins PFA, Boscoli FNS, Consolaro MEL. Avaliação do método de Papanicolaou para triaǵem de algumas infecções cérvico-vaǵinais. Rev Bras Anal Clin 2007;39: 217-221.

147. Campos ACC, Freitas-Júnior R, Ribeiro LFJ, Paulinelli RR, Reis C. Prevalence of vulvovaǵinitis and bacterial vaginosis in patients with koilocytosis. Sao Paulo Med J 2008;126: 333-336.

148. Muvunyi CM, Dhont N, Verhelst R, Crucitti T, Reijans M, Mulders B, Simons G, Temmerman M, Claeys G, Padalko E. Evaluation of a new multiplex polymerase chain reaction assay STDFinder for the simultaneous detection of 7 sexually transmitted disease pathogens. Diaǵn Microbiol Infect Dis 2011;71: 29-37.

149. Schachter J, Hill EC, King EB, Coleman VR, Jones P, Meyer KF. Chlamydial infeetion in women with cervical dysplasia. Am J Obstet Gynecol 1975;123:753-757.

150. Smith JS, Bosetti C, Munoz N, Herrero R, Bosch FX, Eluf-Neto J, Meijer CJ, Van Den Brule AJ, Franceschi S, Peeling RW. Chlamydia trachomatis and invasive cervical cancer: A pooled analysis of the IARC multicentric case-control study. Int J Cancer 2004;111: 431-439.

151. Hakama $M$, Lehtinen $M$, Knekt $P$, Aromaa A, Leinikki P, Miettinen A, Paavonen J, Peto R, Teppo L. Serum antibodies and subsequent cervical neoplasms: a prospective study with 12 years of follow-up. Am J Epidemiol 1993;137:166-170.

152. Anttila T, Saikku P, Koskela P, Bloigu A, Dillner J, Ikaheimo I, Jellum E, Lehtinen M, Lenner P, Hakulinen T, Narvanen A, Pukkala E, Thoresen S, Youngman L, Paavonen J. Serotypes of Chlamydia trachomatis and risk for development of cervical squamous cell carcinoma. JAMA 2001;285:47-51. doi: 10.1001/jama.285.1.47.

153. Wallin KL, Wiklund F, Luostarinen T, Angstrom T, Anttila T, Bergman F, Hallmans G, Ikaheimo I, Koskela P, Lehtinen M, Stendahl U, Paavonen J, Diener J. A population-based prospective study of Chlamydia trachomatis infection and cervical carcinoma. Int J Cancer 2002; 101:371374. doi: 10.1002/ijc.10639.

154. Koskela P, Anttila T, Bjørge T, Brunsvig A, Dillner J, Hakama M, Hakulinen T, Jellum M, Lethinen M, Lenner P, Luostarinen T, Pukkala, Saikku E, Thoresen S, Youngman J, Paavonen J. Chlamydia trachomatis infection as a risk factor for invasive cervical cancer. Int $\mathrm{J}$ Cancer. 2000; 85:35-39. doi: 10.1002/ (sici)1097-0215(20000101)85:1<35::aidijc6>3.0.co;2- $a$.

155. Quint KD, de Koning MN, Geraets DT, Quint WG, Pirog EC. Comprehensive analysis of Human Papillomavirus and Chlamydia trachomatis in in-situ and invasive cervical adenocarcinoma. Gynecol Oncol 2009;114(3):390-394. doi:10.1016/j. yǵyno.2009.05.013.

156. Ghosh I, Mandal R, Kundu P, Biswas J. Association of genital infections other than human papillomavirus with pre-Invasive and invasive cervical neoplasia. J Clin Diaǵn Res. 2016 Feb;10(2):XE01-XE06. doi: $\quad$ 10.7860/JCDR/2016/15305.7173. Epub $2016 \mathrm{Feb1.}$

157. Johnston VJ, Mabey DC. Global epidemiology and control of Trichomonas vaǵinalis. Curr Opin Infect Dis 2008;21(1):56-64. doi:10.1097/QCO.0b013e3282f3d999

158. Paavonen J. Chlamydia trachomatis and cancer. Sex Transm Infect 2001; 77: 154-156.

159. Deluca GD, Basiletti J, Schelover E, DíazVásquez N, Alonso JM, Marin HM, Lucero RH, Picconi MA. Chlamydia trachomatis as a probable cofactor in human papillomavirus infection in aboriginal women from northeastern Argentina. Braz J Infect Dis 2011;15(6):567-572. doi:10.1016/s1413$8670(11) 70252-5$.

160. Gopalkrishna V, Aggarwal N, Malhotra VL, Koranne RV, Mohan VP, Mittal A, Das BC. Chlamydia trachomatis and human papillomavirus infection in Indian women with sexually transmitted diseases and cervical precancerous and cancerous lesions. Clin Microbiol Infect 2000;6(2):88-93. doi:10.1046/j.1469-0691.2000.00024.x

161. Verhoeven V, Baay M, Weyler J, Avonts D, Lardon F, Van Royen P, Vermorken JB. 
Concomitant Chlamydia trachomatis and human papilloma virus infection cannot be attributed solely to sexual behavior. Eur J Clin Microbiol Infect Dis 2004;23(9):735737.

162. Smith JS, Muñoz N, Herrero R, Eluf-Neto J, Ngelangle C, Francheschi S, Bosch FX, Walboomers JMM, Peeling RW. Evidence for Chlamydia trachomatis as a human papillomavirus cofactor in the etiology of invasive cervical cancer in Brazil and the Philippines. J Infect Dis 2002;185(3):324-331. doi:10.1086/338569.

163. Fan T, Lu H, Hu H,Shi L, MeCarty GA, Nance DM, Greenberg AH, Zhong G. Inhibition of apoptosis in chlamydia-infected cells: blockade of mitochondrial cytochrome c release and caspase activation. J Exp Med 1998;187:487-496.

164. Jaiswal M, LaRusso NF, Burgart LJ, Gores GJ. Inflammatory cytokines induce DNA damage and inhibit DNA repair in cholangiocarcinoma cells by a nitric oxide-dependent mechanism. Cancer Res 2000;60: 184-190.

165. Zhu H, Shen $Z$, Luo H, Zhang $W$, Zhu $X$. Chlamydia Trachomatis Infection-Associated Risk of Cervical Cancer: A Meta-Analysis. Medicine (Baltimore). 2016;95(13):e3077. doi:10.1097/MD.0000000000003077.

166. Velicer C, Zhu X, Vuocolo S, Liaw KL, Saah A. Prevalence and incidence of $H P V$ genital infection in women. Sex Transm Dis. 2009;36(11):696-703. doi:10.1097/ OLQ.0b013e3181ad25ff

167. Shew ML, Fortenberry JD, Tu W, Juliar BE, Batteiger BE, Qadadri B, Brown DR. Association of condom use, sexual behaviors, and sexually transmitted infections with the duration of genital human papillomavirus infection among adoleseent women. Arch Pediatr Adolese Med 2006;160(2):151-156. doi: 10.1001/archpedi.160.2.151.

168. Koutsky LA, Holmes KK, Critchlow CW, Stevens CE, Paavonen J, Beckmann AM, DeRouen TA, Galloway DA, Veton D, Kivat NB. A cohort study of the risk of cervical intraepithelial neoplasia grade 2 or 3 in relation to papillomavirus infection. N Enǵl J Med. 1992;327(18):1272-1278. doi:10.1056/NEJM199210293271804.
169. Lehtinen M, Dillner J, Knekt P, Luostarinen T, Aromaa A, Kirnbauer R, Koskela P, Paavonen J, Peto R, Schiller JT, Hakama M. Serologically diagnosed infection with human papillomavirus type 16 and risk for subsequent development of cervical carcinoma: nested case-control study. BMJ 1996;312(7030):537-539. doi: 10.1136/ bmj.312.7030.537.

170. Naucler P, Chen HC, Persson K, You SL, Hsieh CY, Sun CA, Dillner J, Chen CJ. Seroprevalence of human papillomaviruses and Chlamydia trachomatis and cervical cancer risk: nested case-control study. J Gen Virol 2007;88(Pt 3):814-822. doi:10.1099/vir.0.82503-0.

171. Anttila T, Saikku P, Koskela P, Bloigu A, Dillner J, Ikaheimo I, Jellum E, Mehtinen M, Lenner P, Hakulinen T, Narvanen A, Pukkala E, Thoresen S, Youngman L, Paavonwn J.. Serotypes of Chlamydia trachomatis and risk for development of eervical squamous cell carcinoma. JAMA 2001;285(1):47-51. doi:10.1001/jama.285.1.47.

172. Workowski KA, Suchland RJ, Pettinger MB, Stamm WE. Association of genital infection with specific Chlamydia trachomatis serovars and race. J Infect Dis 1992; 166:1445-1449.

173. Kuo CC, Wang SP, Holmes KK, Grayston T. Immunotypes of Chlamydia trachomatis isolates in Seattle, Washington. Infect Immun 1983;41:865-868.

174. Saikku P, Wang SP. Chlamydia trachomatis immunotypes in Finland. APMIS 1987;95:131-134.

175. Moncan T, Eb F, Orfila J. Monoclonal antibodies in serovar determination of 53 Chlamydia trachomatis isolates from Amiens, France. Res Microbiol 1990; 141:695-701.

176. Barnes RC, Rompalo AM, Stamm WE. Comparison of Chlamydia trachomatis serovars causing rectal and cervical infections. J Infect Dis 1987;156:953-958.

177. Poole E, Lamont I. Chlamydia trachomatis serovar differentiation by direct sequence of the variable segment 4 region of the major outer membrane protein gene. Infect Immun 1992; 60:1089-1094. 
178. Barnes RC, Suchland RJ, Wang S-P, Kuo CC, Stamm WE. Detection of multiple serovars of Chlamydia trachomatis in genital infections. J Infect Dis 1985;152:985989.
179. Fan T, Lu H, Hu H, McCarty GA, Nance DM, Greenberg AH, Zhong G. Inhibition of apoptosis in chlamydia-infected cells: blockade of mitochondrial cytochrome c release and caspase activation. J Exp Med 1998;187(4):487496. doi:10.1084/jem.187.4.487. 